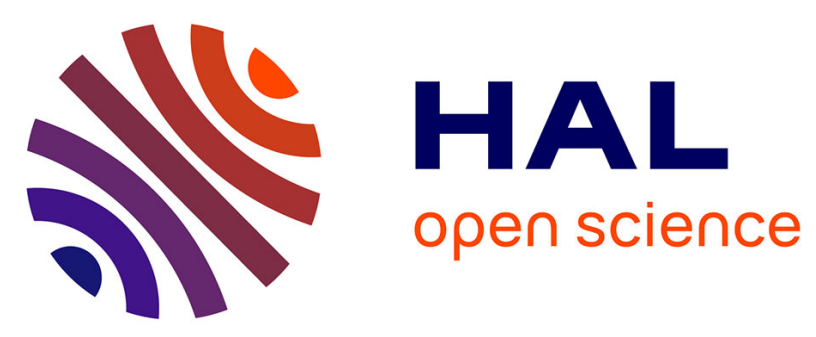

\title{
The formation and reduction of NO during the combustion of powdered petroleum coke -the case of cement plant precalciner conditions
}

Jean-Michel Commandre, Sylvain Salvador, Laurent van de Steene, Roger Gadiou

\section{To cite this version:}

Jean-Michel Commandre, Sylvain Salvador, Laurent van de Steene, Roger Gadiou. The formation and reduction of NO during the combustion of powdered petroleum coke -the case of cement plant precalciner conditions. Combustion Science and Technology, 2005, 177 (3), p. 579-611. 10.1080/00102200590909247. hal-01844745

\section{HAL Id: hal-01844745 \\ https://hal.science/hal-01844745}

Submitted on 6 Nov 2018

HAL is a multi-disciplinary open access archive for the deposit and dissemination of scientific research documents, whether they are published or not. The documents may come from teaching and research institutions in France or abroad, or from public or private research centers.
L'archive ouverte pluridisciplinaire HAL, est destinée au dépôt et à la diffusion de documents scientifiques de niveau recherche, publiés ou non, émanant des établissements d'enseignement et de recherche français ou étrangers, des laboratoires publics ou privés. 


\title{
THE FORMATION AND REDUCTION OF NO DURING THE COMBUSTION OF POWDERED PETROLEUM COKE-THE CASE OF CEMENT PLANT PRECALCINER CONDITIONS
}

\author{
J.-M. COMMANDRÉ \\ S. SALVADOR \\ L. VAN DE STEENE
}

Ecole des Mines d'Albi-Carmaux, Laboratoire de Genie des Procédés et des Solides Divisés, UMR CNRS 2392, Albi CT Cedex, France

\section{R. GADIOU*}

Laboratoire de Gestion des Risques et Environnement, Mulhouse, France

In a cement plant precalciner, petroleum cokes are burned between 800 and $1100^{\circ} \mathrm{C}$ and NO present in the flue gas is mainly fuel NO. We have developed a thermochemical model that describes the combustion of powdered petroleum coke in laminar flow conditions. It takes into account the main thermal and chemical mechanisms which occur during combustion. The formation and reduction mechanisms for fuel, prompt, and thermal NO are modeled; as far as gas-phase reactions are concerned, detailed chemistry is treated. Specific experiments were conducted to characterize the species produced by each of the major reactions and to determine their reaction kinetics. These experiments were performed in an entrained-flow reactor at $900^{\circ} \mathrm{C}$ under conditions typical of those in a precalciner. A gas analysis device based on high-resolution Fourier transform infrared was specifically developed to quantify the main gases which participate in NO formation and destruction. Thanks to this work, 
the main mechanisms were distinguished, and their relative importance in NO formation was established. Gas-phase reactions form most of the NO in the flame zone but contribute only slightly to the final NO emission. The quantity of thermal NO is negligible. Fuel NO is formed principally during combustion of the carbon residue. In compensation, a significant quantity of NO is reduced by heterogeneous reaction with the carbon of the particles.

Keywords: petroleum coke, combustion, NO formation, model

\section{INTRODUCTION}

Because of its contribution to acid rain and photochemical smog, one of the main research and development topics of the past three decades has been the reduction of $\mathrm{NO}_{\mathrm{x}}$ emissions from industrial plants. The control of $\mathrm{NO}_{\mathrm{x}}$ emissions from cement plants is of major concern because they use large amounts of solid fuels, which can lead to significant $\mathrm{NO}_{\mathrm{x}}$ emissions (EPA, 1994). The fuel consumption of a cement plant is typically 140 tons per day. Coal is the main energy source in cement manufacturing, but petroleum coke is also used extensively as a fuel because its cost has fallen to virtually zero; nevertheless, the quality has simultaneously declined. For example, the sulfur contents have risen to the order of $5-7 \%$ and the mineral matter content has also increased. These changes have led to modifications of the combustion systems of plants using these fuels. The work described here was a part of an investigation into the use of petroleum cokes in the precalciners of cement kilns.

A modern cement plant is equipped with a precalciner: this reactor burns up to $60 \%$ of the total amount of fuel. It allows a lower energy consumption at the plant while at the same time increasing its production. Therefore, $\mathrm{NO}_{\mathrm{x}}$ can be produced in the rotary kiln or in the precalciner. Because of the high temperature of the kiln, thermal-NO and fuel-NO formation can be observed in this part of the process. On the contrary, the intimate mixing between raw meal (mainly $\mathrm{CaCO}_{3}$ that is converted to $\mathrm{CaO}$ ) and solid fuel inside the precalciner enables combustion at low temperatures (in the range $800-1100^{\circ} \mathrm{C}$ ). A precalciner, therefore, produces almost no quantities of thermal NO, but significant fuel-NO quantities are generated. The high temperature of the rotary kiln cannot be modified because it is needed by the clinker fabrication process, but the precalciner design can be improved to reduce $\mathrm{NO}_{\mathrm{x}}$ emissions. The aim of this work was to quantify the contribution of 
the different mechanisms to the formation and the destruction of NO in the precalciner.

The analysis of the main reactions of combustion (e.g., devolatilization, char oxidation, and volatile matters oxidation) is essential to describe the mechanisms of NO formation and destruction. Iliuta et al. (2002a, 2002b) developed a mathematical modeling of a cement plant calciner which uses coal, and the authors observed a strong influence of the fuel combustion rate on the $\mathrm{NO}_{\mathrm{x}}$ formation and reduction. This was related not only to the local temperature and pressure influence, but also to the local solid carbon concentration, which influences the heterogeneous reduction of NO. The importance of this heterogeneous reduction is also increased by the fact that the gas that enters the calciner from the rotary kiln contains significant amounts of NO. The importance of volatile matter content of the fuel used in precalciners has also been noticed (Johansen et al., 1986).

However, devolatilization and char oxidation kinetic parameters concerning petroleum cokes are rarely indicated in the literature. The wide variation of reactivities of petroleum cokes toward oxygen has already been demonstrated in a previous paper, it has been shown that these variations can be correlated with catalytic effects of vanadium (Commandré et al., 2002; Salvador et al., 2002).

The process of release of the fuel nitrogen during the combustion of petroleum coke is also not well known. Although the reduction of NO by carbonaceous solids has been the aim of many studies since the 1980s, numerous uncertainties still remain. In many studies, global kinetic laws have been fitted with experimental data. But large variations are observed between published data whatever the temperature (Aarna and Suuberg, 1997). These differences can be related either to surface reactivity effects or to textural properties of the carbonaceous solids (Illan-Gomez et al., 1993, 1995). As for coal chars, petroleum coke samples exhibit large variations in reactivities toward NO.

We have conducted specific experiments of petroleum coke devolatilization and coke combustion to characterize the species produced by each of the major reactions and to determine their reaction kinetics. These experiments were performed in an entrained-flow reactor (EFR) under conditions typical of those in a precalciner. During these reactions, the fate of nitrogen is studied by measuring nitrogen species concentrations in the gas phase, using a specific sampling probe and high-resolution FTIR. 
A thermochemical model was developed to describe the combustion of powdered petroleum coke in EFR conditions (laminar flow). It takes into account all the thermal and chemical mechanisms that occur during the combustion. The formation and reduction mechanisms for fuel, prompt, and thermal NO are modeled. Previously published studies on coal combustion have shown that it is important to take into account the coupling between homogeneous and heterogeneous reactions (Goel et al., 2002). In this work, as far as gas-phase reactions are concerned, detailed chemistry was treated and coupled with the particle combustion submodel.

\section{THERMOCHEMICAL MODEL}

The basic assumption of the model is that the EFR is a one-dimensional plug-flow reactor fed with

- a preheated gas flow (air or nitrogen);

- a solid particle's flow which is perfectly dispersed in the gas flow.

Because of the entrained-flow assumption, the whole flow is simulated considering a single particle and the gas volume that can be associated with it. For the same reason, there is no slip velocity between the particles and the gas phase. All equations are written for this biphasic cell. The assumption of no particle interactions is implicitly made. The particles are supposed to be spherical and the particle size is assumed to be $65 \mu \mathrm{m}$, which is the mean value of the grind fraction 30-100 $\mu \mathrm{m}$ (see "Materials" section). It is assumed that the diameter is constant during the combustion. The particle's temperature is supposed to be homogeneous inside and is computed through a heat balance including

- conductive heat exchange with the gas phase,

- radiative heat exchange with the furnace wall, and

- heat source terms from heterogeneous reactions.

The particle composition is initially described in terms of $\mathrm{C}, \mathrm{H}, \mathrm{O}, \mathrm{N}, \mathrm{S}$, and ash percentages. The mass of the particle is supposed to be the sum of the masses of coke, char (initially at zero), and ash. The mass of each component is computed along the combustion at each time step. 


\section{Main Reactions}

Devolatilisation. The mass loss rate due to the conversion of coke into char and gases is described with a classical single reaction kinetic model:

$$
\frac{\partial \boldsymbol{m}_{\mathrm{coke}}}{\partial \boldsymbol{t}}=\boldsymbol{k}_{\mathrm{dev}} \boldsymbol{m}_{\mathrm{coke}}
$$

with

$$
k_{\mathrm{dev}}=A_{\mathrm{dev}} \exp \left(-\frac{E_{a \mathrm{dev}}}{R T_{p}}\right)
$$

The volatiles are assumed to be composed of $\mathrm{CO}, \mathrm{CH}_{4}$ (light hydrocarbons), $\mathrm{C}_{3} \mathrm{H}_{3}$ (heavy hydrocarbons), nitrogen species $\left(\mathrm{N}_{2}, \mathrm{NO}\right.$, $\left.\mathrm{N}_{2} \mathrm{O}, \mathrm{HCN}, \mathrm{NH}_{3}\right)$, and sulfur dioxide $\left(\mathrm{SO}_{2}\right)$. The fractions of $\mathrm{CO}$ and $\mathrm{CH}_{4}$ are obtained from the pyrolysis experiments, and the fraction of $\mathrm{C}_{3} \mathrm{H}_{3}$ is computed from the carbon balance during devolatilization.

Char Oxidation. This reaction converts the carbon into $\mathrm{CO}$ and $\mathrm{CO}_{2}$; the ratio between these two species is computed from an Arrhenius-type law (Arthur, 1951):

$$
r_{\mathrm{mas}}=\frac{m_{\mathrm{CO}}}{m_{\mathrm{CO}_{2}}}=2500 \exp \left(-\frac{51,843 \mathrm{~kJ} / \mathrm{mol}}{R T_{p}}\right)
$$

The kinetic model is

$$
\frac{\partial m_{\mathrm{ox}, \mathrm{C}}}{\partial t}=-\boldsymbol{k}_{\mathrm{ox}, \mathrm{C}} \boldsymbol{m}_{C} \eta_{\mathrm{ox}} S_{\mathrm{sp}} P_{\mathrm{O}_{2}}, \boldsymbol{s}
$$

with

$$
k_{\mathrm{ox}, \mathrm{C}}=A_{\mathrm{ox}, \mathrm{C}} \exp \left(-\frac{E_{a \mathrm{ox}, \mathrm{C}}}{R T_{p}}\right)
$$

The specific surface area $S_{\mathrm{sp}, \mathrm{C}}$ of the porous carbon residue was measured by BET with $\mathrm{N}_{2}$ at $77 \mathrm{~K}$. The effectiveness factor $\eta_{\text {ox }}$ was computed for a spherical particle from the Thiele modulus (Thiele, 1939):

$$
\eta_{\mathrm{ox}}=\frac{3}{\Phi}\left(\frac{1}{\tanh \Phi}-\frac{1}{\Phi}\right)
$$

with, for a first-order reaction,

$$
\Phi=\frac{d_{\mathrm{pore}}}{2} \sqrt{\frac{k_{\mathrm{ox}, \mathrm{C}} S_{\mathrm{sp}}}{\rho_{g} D_{e}}}
$$


The effective diffusivity must take into account the Fick and Knudsen diffusion in the pores; it is calculated as follows (Laurendeau, 1978):

$$
D_{e}=\left(\frac{1}{D_{\text {Fick }}}-\frac{1}{D_{\text {Knud }}}\right)^{-1} \frac{\varepsilon_{p}}{\tau_{p}}
$$

in which the particle porosity was measured by helium picnometry $\left(\varepsilon_{p}=0.593\right)$, and the tortuosity $\tau_{p}$ was assumed to be 4 . The Knudsen diffusivity was calculated as follows (Wheeler, 1951):

$$
D_{\mathrm{Knud}}=\frac{d_{\mathrm{pore}}}{3} \sqrt{\frac{8 R T_{\mathrm{env}}}{M_{\mathrm{O}_{2}}}}
$$

The mean pore diameter was calculated from the surface area $S_{\mathrm{sp}}$ (Wheeler, 1951):

$$
d_{\text {pore }}(m)=\frac{4 \varepsilon_{p}}{\rho_{p} S_{\text {sp }}}
$$

The surface area was measured with the BET method applied on nitrogen adsorption isotherm at $77 \mathrm{~K}\left(S_{\mathrm{sp}}=5.3 \mathrm{~m}^{2} / \mathrm{g}\right)$ and the true density was obtained from helium picnometry $\left(\rho_{p}=1640 \mathrm{~kg} / \mathrm{m}^{3}\right)$. The influence of the temperature on the molar diffusivity was computed as (Laurendeau, 1978)

$$
D_{\text {Fick }}\left(m / s^{2}\right)=1.7 \times 10^{-5}\left(\frac{T+273}{273}\right)^{\frac{3}{2}}
$$

Char oxidation also produces minor species: nitrogen species $\left(\mathrm{N}_{2}, \mathrm{NO}\right.$, $\mathrm{N}_{2} \mathrm{O}, \mathrm{HCN}, \mathrm{NH}_{3}$ ) and sulfur dioxide.

Gas Phase. The gas phase is supposed to be homogeneous in temperature and in concentration on a cross section of the reactor (onedimensional plug-flow definition). The temperature is computed from a heat balance equation that includes

- conductive heat exchange with the particle,

- convective heat exchange with the furnace wall, and

- heat source terms from the homogeneous (gas-phase) chemical reactions. 
The gas-phase composition is computed including

- mass source terms from the particle (devolatilization, char oxidation, NO reduction on char) and

- chemical reactions inside the gas phase.

In most biphasic combustion simulations, a simplified gas-phase kinetic mechanism is used (Iliuta et al., 2002a). This allows the calculation of species concentrations while saving computing time. In our simulation, detailed chemistry with reversible reactions is used. The volatiles oxidation and nitrogen species reactions are treated with the Miller and Bowman scheme (Miller and Bowman, 1989) which includes 62 species and 266 reactions. We have added Wendt's scheme to describe the sulfur species chemistry (Wendt et al., 1983). This enables us to study potential interactions between nitrogen and sulfur gaseous species. The reaction rates and energy source terms are computed using the CHEMKIN software subroutines (Kee et al., 1990).

Further simulations have been done with the recently published mechanism of Dagaut et al. (Dagaut and Lecomete, 2003). This mechanism also includes the reactions for sulfur species and for the interaction between sulfur and nitrogen chemistry. Although some small differences were found between the two mechanisms for some intermediate species in trace concentrations, no significant change was observed for the main species.

\section{Nitrogen Species}

The nitrogen initially present inside the particle is released partly during the devolatilization and partly during the char oxidation. The release of fuel nitrogen during devolatilization is a complex function of the fuel nature, temperature, and heating rate (Baxter et al., 1996). The fraction of coke nitrogen which is devolatilized is $\alpha$; it is often assumed to be proportionnal to the devolatilization yield (Förtsch et al., 1998). In our case, this parameter was obtained from a nitrogen balance between char and coke. The parameters for the conversion ratio of $\mathrm{N}$ char to the nitrogen-containing species $\mathrm{NO}, \mathrm{N}_{2} \mathrm{O}, \mathrm{N}_{2}, \mathrm{HCN}$, and $\mathrm{NH}_{3}$ are $\eta_{\mathrm{C}}$, $\beta_{\mathrm{C}}, \gamma_{\mathrm{C}}, \delta_{\mathrm{C}}$, and $\varepsilon_{\mathrm{C}}$, respectively. The corresponding parameters for the conversion of primary $\mathrm{N}$-volatile species are $\eta_{V}, \beta_{V}, \gamma_{V}, \delta_{V}$, and $\varepsilon_{V}$, respectively. This model is based on that of Song (Song et al., 1977). 
Depending on the experimental conditions and the nature of the fuel, other nitrogen-containing species may be condidered. HNCO has also been observed during fuel devolatilization (Nelson et al., 1996), tar cracking (Ledesma et al., 1998), and oxidation (Johnsson, 1994; Nicholls and Nelson, 2000). This observation was done mainly with low-rank fuels in fluidized-bed boilers (Amand et al., 1991; Glarborg et al., 2003; Kramlich and Linak, 1994; Li et al., 1996). In the case of high-rank fuels with a low volatile matter content, HNCO was in low concentration. This molecule was not detected during the EFR experiments of Zhang and Fletcher (2001). Furthermore, HCNO seems to be a product of the decomposition of fuels at low temperature, which decompose to $\mathrm{HCN}$ in most cases as the temperature increases (Ledesma et al., 1998). This species was not analyzed in this work.

As soon as a gaseous $\mathrm{N}$ species is generated by the particle, its chemical behavior is computed by the detailed gas-phase scheme (just as for the other gas species). NO is reduced by heterogeneous reaction on the surface of the porous char:

$$
\frac{\partial \boldsymbol{m}_{\mathrm{NO}, \mathrm{C}}}{\partial t}=-\boldsymbol{M}_{\boldsymbol{c}} \boldsymbol{k}_{\mathrm{NO}, \mathrm{C}} \boldsymbol{m}_{c} \eta_{\mathrm{NO}} S_{\mathrm{sp}} P_{\mathrm{NO}, s}
$$

with

$$
k_{\mathrm{NO}, \mathrm{C}}=A_{\mathrm{NO}, \mathrm{C}} \exp \left(-\frac{E_{a \mathrm{NO}, \mathrm{C}}}{R T_{p}}\right)
$$

During pyrolysis experiments, tar quantities in volatile matter have been found to be an important part of volatile matters. Nevertheless, tars are not taken into account in the model. As far as tar's carbon is concerned, it is considered carbon residue. We implicitly assume that the nitrogen that should be released in tars remains inside the carbon residue. Guo has shown that the concentration of $\mathrm{N}$ species in the tars was similar to that of the char residue (Guo and Hecker 1998). Tars and char will both oxidize during the combustion; nevertheless, the description of tar's oxidation kinetics in this temperature range remains difficult. This remains a weak point in models such as the one described here.

\section{Sulfur Species}

Sulfur is present in petroleum coke mainly as organic species (Al-Haj-Ibrahim and Morsi, 1992); several sulfur-containing species can therefore be 
devolatilized. Nevertheless, a fast oxidation is assumed so that the sulfur initially present inside the particle is released as $\mathrm{SO}_{2}$, partly during the devolatilization and partly during the char oxidation (Adanez et al., 1996). The amount of sulfur devolatilized increases with temperature (Uzun and Ozdogan, 1998). We make the assumption that the release is proportional to the particle's mass loss; we will show some experimental evidence that it happens like this.

It is known that the amount and the nature of the mineral matter present in a fuel can influence the amount of sulfur available for gasphase reactions (Fuertes and Artos, 1992; Sheng et al., 2000). This phenomenon is often related to the presence of calcium in the fuel, which can be present in petroleum coke (Salvador et al., 2004). In this work, the mineral matter content of the petroleum coke is very low compared to its sulfur content. We did not take into account any reaction between sulfur species and mineral matter. Furthermore, the analysis of the mineral matter of this petroleum coke showed that the amount of calcium was very low ( $20 \mathrm{ppm}$ on a raw basis).

\section{Numerical Integration}

All the equations (particle heat balance equation, gas-phase heat balance equations, and the gas-phase chemistry equations) are time-integrated simultaneously with the help of the Gear algorithm, which can solve "stiff" ordinary differential equation systems (Radhakrishnan and Hindmarsh, 1993). The whole model is included in a FORTRAN 77 program. As pointed out in the beginning of this section, there is no slip velocity between gas and particles; therefore, a one-dimensional mesh was built to simulate the tubular reactor. The devolatilization and heterogeneous reactions were coupled with the gas-phase chemistry; the differential equation used to compute the mass of each species $i$ in a cell was

$$
\left(\frac{\partial \boldsymbol{m}_{i}}{\partial \boldsymbol{t}}\right)=\sum_{j=1}^{n_{\text {het }}}\left(\frac{\partial \boldsymbol{m}_{i}}{\partial \boldsymbol{t}}\right)_{\eta_{\text {het }, j}}+\sum_{j=1}^{n_{\text {hom }}}\left(\frac{\partial \boldsymbol{m}_{i}}{\partial \boldsymbol{t}}\right)_{r_{\text {hom }, j}}
$$

The heterogeneous reactions $r_{\text {het }, j}$ are coke oxidation, devolatilization, and NO heterogeneous reduction as described in the preceding sections. The homogeneous reactions $r_{\mathrm{hom}, j}$ are of the gas-phase mechanism and were computed with the CKWYP routine of 
the CHEMKIN package. The following equation was used for the gasphase enthalpy:

$$
\left(\frac{\partial \boldsymbol{h}_{\mathrm{gas}}}{\partial \boldsymbol{t}}\right)=\left(\frac{\partial \boldsymbol{h}}{\partial \boldsymbol{t}}\right)_{\mathrm{part}}+\left(\frac{\partial \boldsymbol{h}}{\partial \boldsymbol{t}}\right)_{\text {wall }}+\left(\frac{\partial \boldsymbol{h}}{\partial \boldsymbol{t}}\right)_{\mathrm{hom}}
$$

in which the subscript "part" indicates the heat transfer between gas phase and particles, and "wall" the heat transfer between gas phase and reactor wall.

\section{EXPERIMENTAL}

\section{Materials}

The petroleum coke (petcoke) used in this study was sampled in an industrial site; no data concerning its origin are available. Table 1 gives the results of ultimate analysis $(\mathrm{C}, \mathrm{H}, \mathrm{O}, \mathrm{N}, \mathrm{S})$, proximate analysis (volatile matter and ashes), and specific surface area measured by BET, HCV, and LCV. Prior to all analyses and experiments, the petcoke was ground, dried, and the fraction $30-100 \mu \mathrm{m}$ was selected by pneumatic sieving. Particles smaller than $30 \mu \mathrm{m}$ in diameter were removed to enable regular feeding of the fuel during EFR experiments.

\section{Experimental Device}

The combustion is operated in an EFR whose design details have been described precisely before (Van De Steene et al., 2000). The fuel heating rate is close to that found in a precalciner cement plant. The apparatus shown in Figure 1 consists of an 80-mm-i.d. and 1-m-long isothermal

Table 1. Characterization of the petroleum coke (oxygen content was obtain by difference)

\begin{tabular}{lc}
\hline C (\% raw) & 89.4 \\
H (\% raw) & 3.60 \\
O (\% raw) & 1.10 \\
S (\% raw) & 4.02 \\
N (\% raw) & 1.88 \\
VM $(\%$ raw $)$ & 10.1 \\
Ash $(\%$ raw $)$ & 0.47 \\
HCV $(\mathrm{kJ} / \mathrm{g})$ & 35.35 \\
LCV $(\mathrm{kJ} / \mathrm{g})$ & 34.50 \\
BET $\left(\mathrm{m}^{2} / \mathrm{g}\right)$ & 5.3 \\
\hline
\end{tabular}




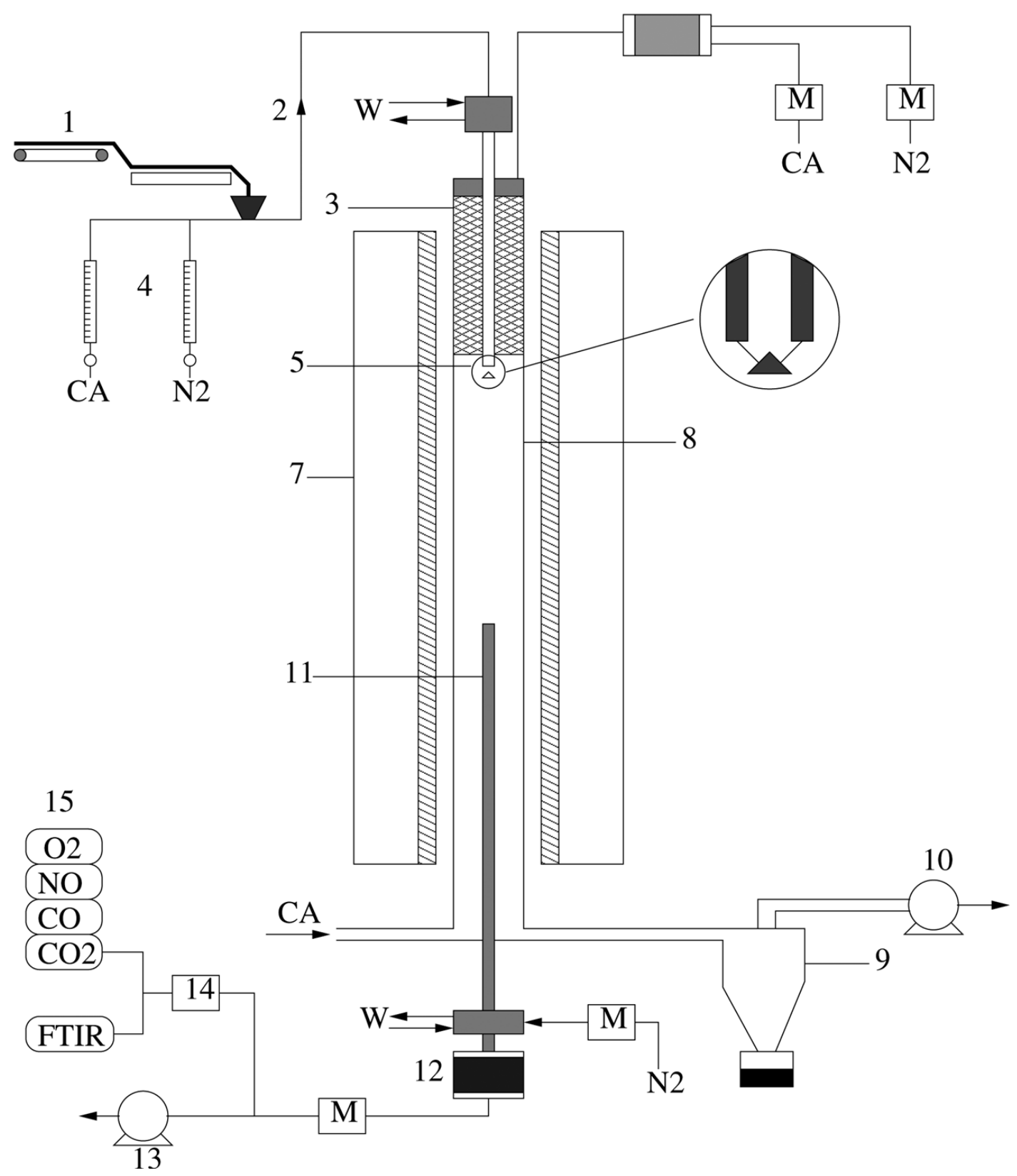

Figure 1. Entrained flow reactor: (1) conveyor belt/vibrating corridor/ejector; (2) pneumatic transport; (3) electrical preheater; (4) flow meters; (5) water-cooled feeding probe; (6) dispersion cone; (7) three-zone electrical furnace; (8) 80-mm-i.d. quartz tube reactor; (9) cyclone collector; (10) exhaust fan; (11) water-cooled nitrogen-quenched sampling probe; (12) particle collector (filter); (13) sampling pump; (14) gas conditioner; (15) gas analyzers (infrared/paramagnetic/FTIR); (M) mass flow meters and controllers; $\left(\mathrm{N}_{2}\right)$ nitrogen; (CA) compressed Air; (W) water (probes cooling).

quartz reactor fed with an electrically preheated laminar atmosphere gas flow. The powdered solid fuel is injected through a water-cooled feeding probe and is dispersed on the cross section of the reactor with the help of 
a small conical device attached within $10 \mathrm{~mm}$ of the outlet of the probe. The fuel burns during a controlled residence time (typically several seconds). A mobile probe was then used to isokinetically presample gas and particles. This sampling proble was water cooled, and it allows mixing the sampled flow with a nitrogen flow at ambient temperature. The gas-phase and heterogeneous reactions were then quickly quenched by the cooling and dilution of the flow.

A specific device was realized to continuously quantify gases by IR absorption $\left(\mathrm{CO}, \mathrm{CO}_{2}, \mathrm{~N}_{2} \mathrm{O}\right)$, paramagnetic analysis $\left(\mathrm{O}_{2}\right)$, and highresolution FTIR ( $\mathrm{NO}, \mathrm{NO}_{2}, \mathrm{HCN}, \mathrm{NH}_{3}$ ). Before any measurement, a calibration of the analyses setup was done by injecting a known concentration of the differents species into the reactor at $900^{\circ} \mathrm{C}$. After calibration, the relative error of measured concentrations was below $5 \%$.

Pyrolysis experiments were carried on with $1.5 \mathrm{~g} / \mathrm{min}$ of petcoke injected in $181 / \mathrm{min}(\mathrm{NTP})$ of nitrogen preheated at $900^{\circ} \mathrm{C}$, inside the EFR which was also heated at $900^{\circ} \mathrm{C}$. Gases were analyzed along the reactor with the mobile sampling probe as described earlier.

Typical experiments for the petcoke's combustion were performed with an airflow equal to $181 / \mathrm{min}$ (NTP) and a coke mass flow ranging between 1.5 and $1.7 \mathrm{~g} / \mathrm{min}$. The inlet air flow was preheated to $900^{\circ} \mathrm{C}$ and the furnace temperature was also $900^{\circ} \mathrm{C}$. These experimental conditions lead to an equivalence ratio ranging between 0.7 and 0.8 . (The equivalence ratio is defined as the molar $\mathrm{C} / \mathrm{O}_{2}$ ratio computed from inlet coke and airflows.) Gases were analyzed along the reactor as described earlier.

For some experiments, the temperature was measured along the axis of the reactor using a specific probe composed of five thermocouples supported by a 2-m-long ceramic tube, and uniformly distributed on a horizontal cross section of the reactor. The thermocouples used to measure the temperature of the gas phase inside the reactor were of $K$ type. The 500- $\mu \mathrm{m}$-diameter wires were welded to form 1-mm-diameter beads. A correction was made on the recorded temperature to calculate the actual gas temperature. This was achieved from an energy balance for each thermocouple bead, taking into account the convective heat transfer between the gas phase and the bead, and the radiative heat transfer between the reactor walls and the bead. The temperature of the reactor walls was measured using three 3-mm-diameter refractory steel sheathed thermocouples that were maintained in contact with the outside walls of the rector tube. The correction reached maximum values of $30^{\circ} \mathrm{C}$. It was observed that, at a given height in the tubular reactor, the radial 
temperature gradients are low. Therefore, for a given cell (i.e., at a given height in the reactor), an average value for the five thermocouples was calculated to obtain a one-dimensional profile along the axis of the reactor. Experiments have been repeated, and indicate similar results, with a typical deviation of $20 \mathrm{~K}$.

\section{DETERMINATION OF THE PARAMETERS REQUIRED BY THE MODEL}

\section{Validation of the Thermal Model}

Prior to the use of the model to determine kinetic parameters of various reactions, it is necessary to validate the thermal balance equations that are used. A set of experiments have been done as described in the previous section with an equivalence ratio of 0.8 , and the temperature profiles along the reactor have been measured.

In Figure 2 we have plotted the model-computed temperature profile for particle and gas phase (respectively, $T_{p}$ and $T_{\text {env }}$ ), together with

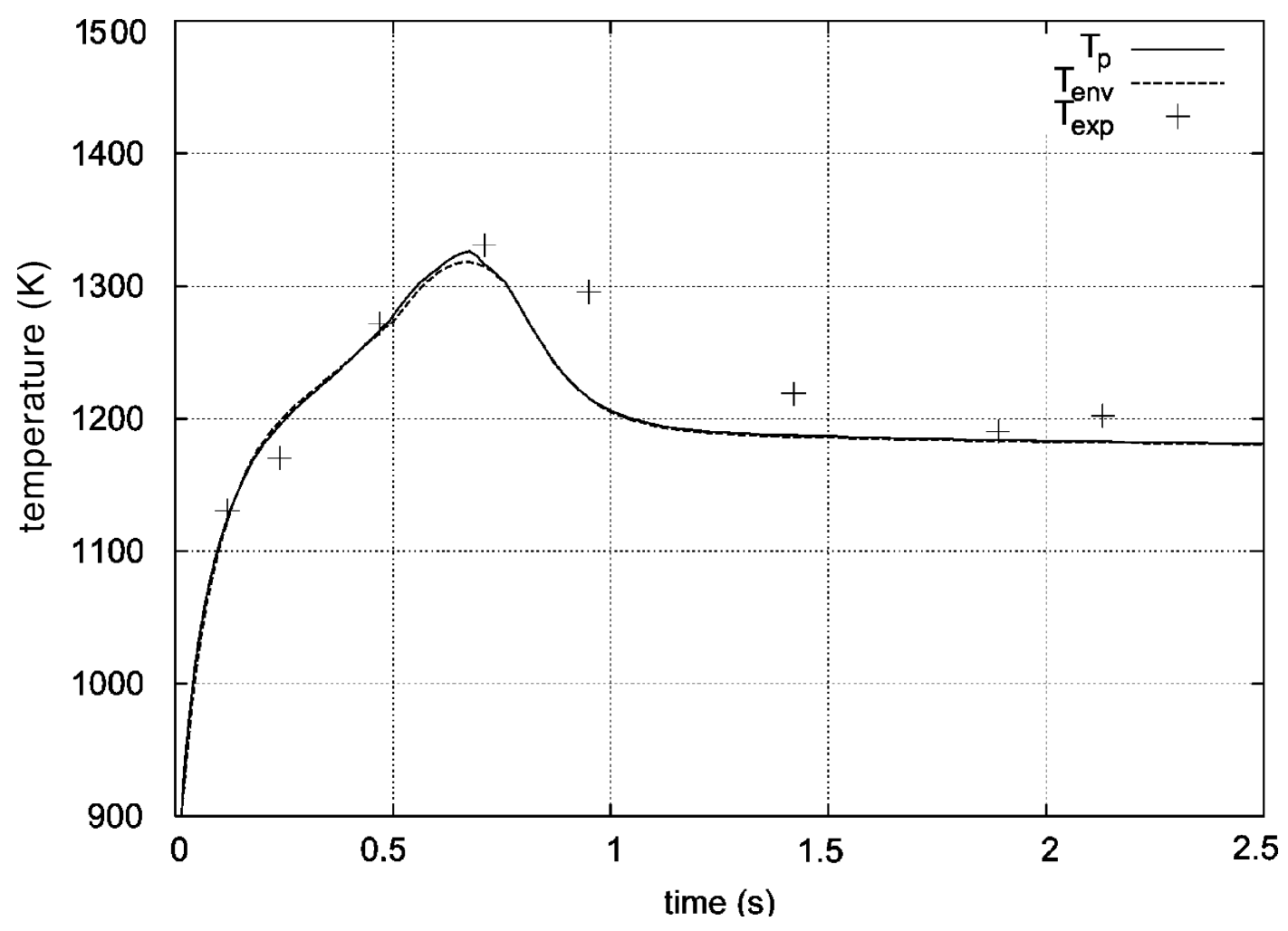

Figure 2. Temperature profile during the combustion of petcoke at $900^{\circ} \mathrm{C}$ with an equivalence ratio of 0.8 ( $T_{p}$, particle temperature; $T_{\text {env }}$; computed gas temperature; $T_{\text {exp }}$, measured gas temperature). 
experimental temperature measurements $T_{\text {exp }}$. It can be seen that the particle and gas-phase temperatures are very close to each other; this can be explained by the small size of the particles, which enhances the heat loss and the relatively low heat generation rate related to the low volatile matter content and the low reactivity of petcokes.

A satisfactory agreement has been reached by adjusting the heat transfer coefficient between the gas phase and the reactor walls. These results show that a flame zone exists for residence time shorter than $1 \mathrm{~s}$. The highest temperature reached is $1060^{\circ} \mathrm{C}$; it corresponds to the volatile matter combustion zone. We can see in Figure 2 that the computed temperatures decrease too quickly in the postcombustion zone. This may be related to the fact that we assumed a one-dimensional plug-flow reactor without diffusion. The diffusion of heat and mass along the axis of the reactor could smooth this temperature decrease for residence times above $0.75 \mathrm{~s}$.

\section{Determination of the Kinetic Parameters for the Devolatilization Reaction}

The kinetic parameters for the devolatilization reaction, $A_{\mathrm{dev}}$ and $E_{\mathrm{dev}}$, were determined by fitting the model-predicted gas-phase composition with the experimental one from a specific experiment in the EFR using an $\mathrm{N}_{2}$ atmosphere as described in "Experimental Device." The model has the advantage of describing the particle's heating period; this is particularly important in the case of a rapid reaction such as the devolatilization, because the chemical reaction progresses significantly before the particle reaches the furnace temperature. The CHEMKIN submodel was used to study the evolution of the primary volatile matters along the reactor.

As far as the activation energy is concerned, we have adopted a value from the literature to minimize the number of experiments (Kobayashi et al., 1976). In Figure 3 we have plotted the experimental molar fractions of a number of species along the EFR together with the model-predicted ones. A good agreement between experimental results and numerical simulations is achieved by fixing $A_{\mathrm{dev}}$ and $E_{a_{\mathrm{dev}}}$ to $1.34 \times 10^{5} \mathrm{~g} / \mathrm{g} \cdot \mathrm{s}$ and $110 \mathrm{~kJ} / \mathrm{mol}$, respectively. It can be seen in this figure that the model underpredicts the amount of ethylene and acetylene; the reason is that these species are only formed through secondary reactions by the kinetic mechanism in our model. $\mathrm{C}_{2} \mathrm{H}_{2}$ and $\mathrm{C}_{2} \mathrm{H}_{4}$ are probably present in 


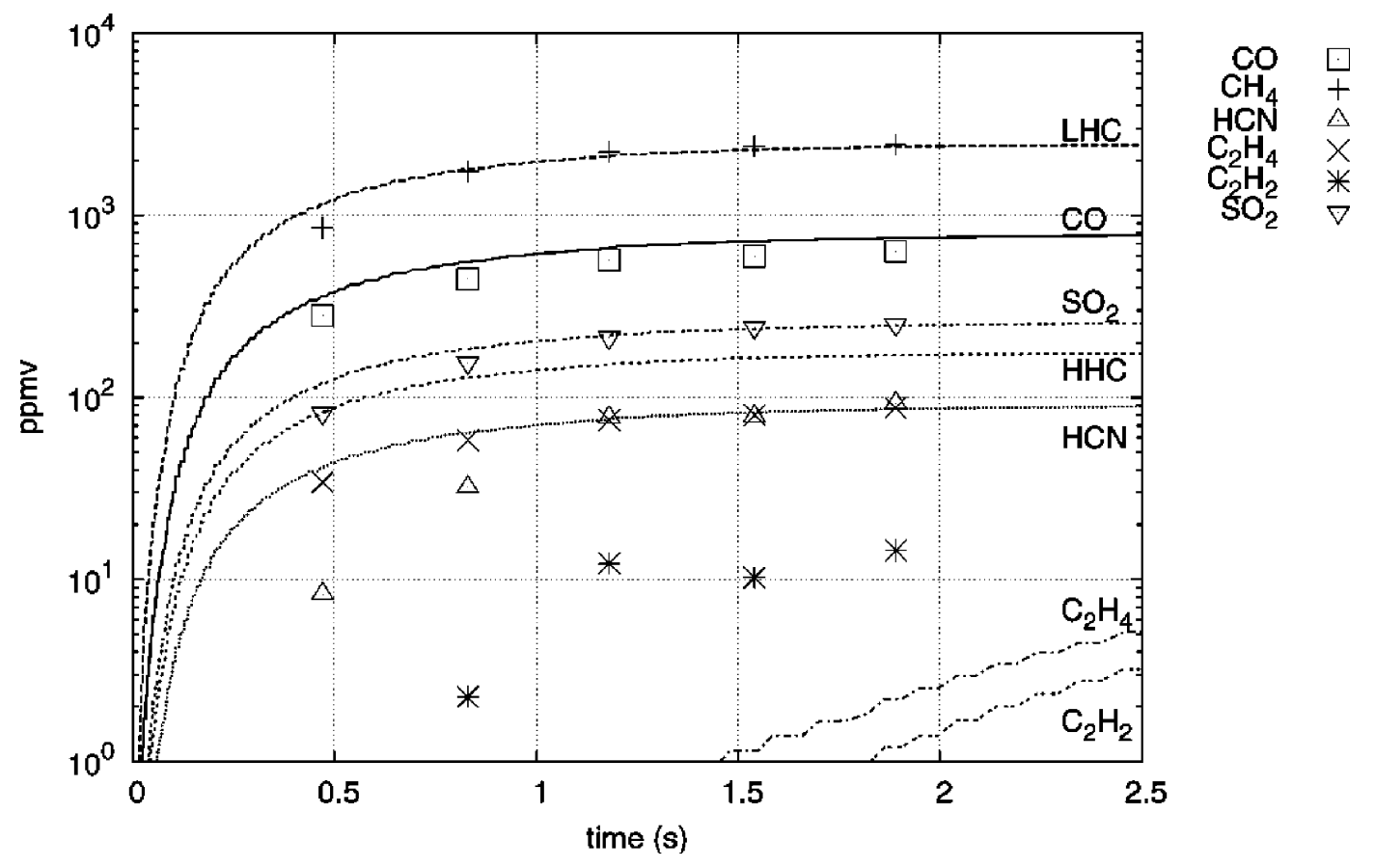

Figure 3. Numerical simulation and experimental results of the petcoke pyrolysis gases (lines; model; symbols; experiments).

the primary volatiles in low concentrations. We can see in Figure 3 that there are some discontinuities in the computed profiles of temperatures. These artifacts are only related to the meshing of the reactor; because of the high rates of the gas-phase reactions, an equilibrium is quickly obtained in each cell. This observation will be true for all subsequent figures. As a consequence, the analysis of the chemical pathways must take into account that the gas phase is in pseudo-equilibrium for many species such as ammonia or hydrogen cyanide.

\section{Determination of the Kinetic Parameter for the Char Oxidation}

The kinetic parameters for the oxidation of the char, $A_{\mathrm{Ox}, \mathrm{C}}$ and $E_{a \mathrm{Ox}, \mathrm{C}}$, were adjusted by fitting numerical simulations with petcoke oxidation experimental results; $1.5 \mathrm{~g} / \mathrm{min}$ of petcoke were fed inside $181 / \mathrm{min}$ (NTP) of air that was preheated at $900^{\circ} \mathrm{C}$. The furnace wall temperature was still $900^{\circ} \mathrm{C}$. These experimental conditions lead to an excess air of $32 \%$. The activation energy of $179.4 \mathrm{~kJ} \mathrm{~mol}^{-1}$ suggested by Smith (1978) is the result of an important review and has been adopted in this work. In addition, this value agrees very well with the activation energy obtained previously in our laboratory with this fuel in slightly different 


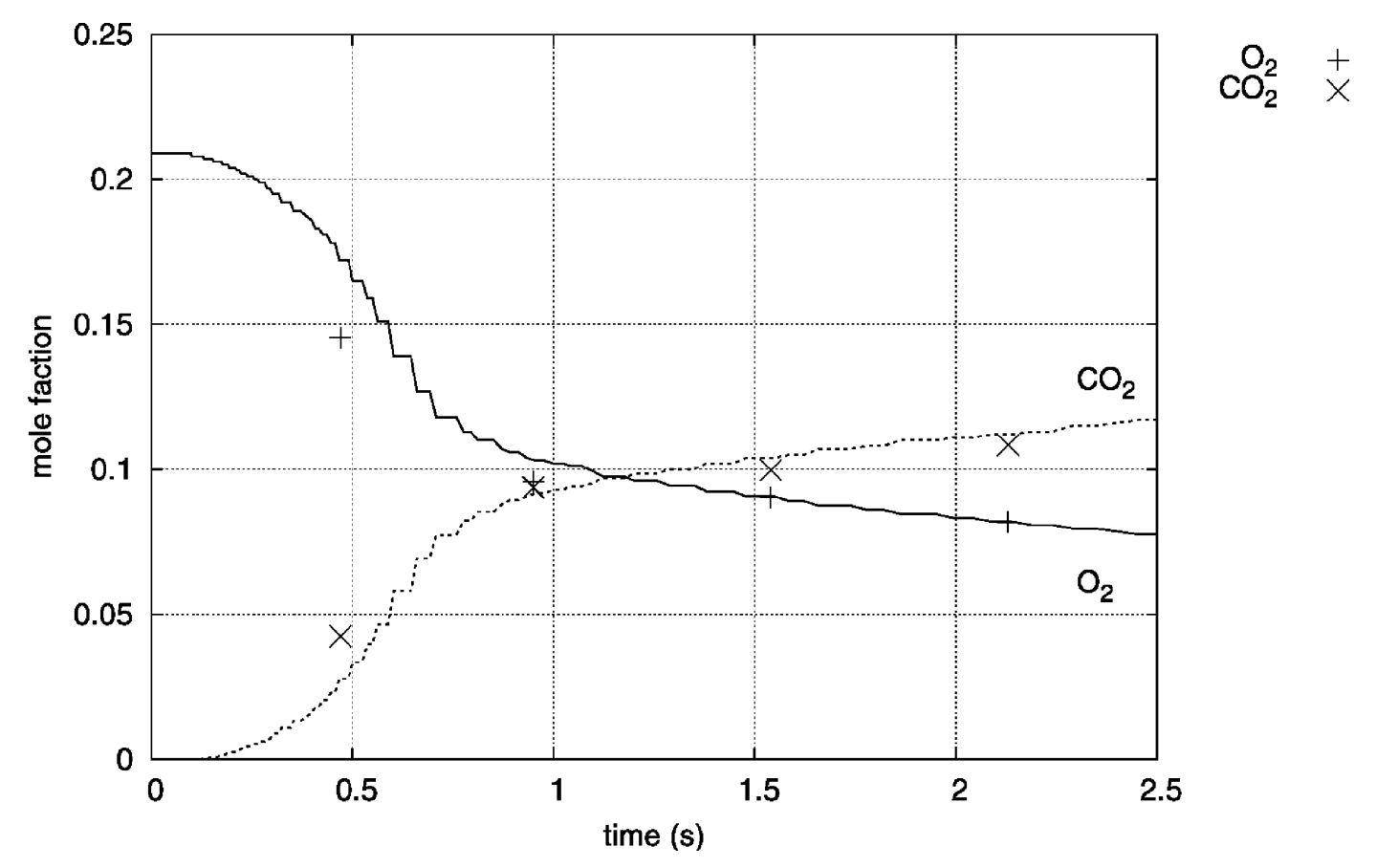

Figure 4. Molar fractions of $\mathrm{O}_{2}$ and $\mathrm{CO}_{2}$ during combustion of petcoke (lines, model; symbols, experiments).

experimental conditions $\left(185 \mathrm{~kJ} \mathrm{~mol}^{-1}\right.$ ) (Salvador et al., 2004). Figure 4 shows experimental results together with numerical results using $A_{\mathrm{Ox}, \mathrm{C}}=5.7 \times 10^{4} \mathrm{~kg} \mathrm{~m}^{-2} \mathrm{~s}^{-1} \mathrm{~atm}^{-1}$; good agreement is obtained.

\section{Determination of the Kinetic Parameter for the Reduction of NO on the Char Surface}

The kinetic parameters have been obtained in a previous work; the details of experiments and calculations are given elsewhere (Commandré et al., 2002). The experiments consisted of injecting $1.5 \mathrm{~g} / \mathrm{min}$ of a char previously prepared in an atmosphere of $955 \mathrm{ppmv}$ of $\mathrm{NO}$ in nitrogen. The NO concentration at the exit of the EFR was quantified, which enabled the determination of the kinetic constants. The model has been described in "Nitrogen Species." A good agreement between experimental and computed NO concentrations was obtained with $A_{\mathrm{NO}, \mathrm{C}}=6.33 \times 10^{6}$ moles m$^{-2} \mathrm{~s}^{-1} \mathrm{~atm}^{-1}$ and $E_{a \mathrm{NO}, \mathrm{C}}=185 \mathrm{~kJ} \mathrm{moles}^{-1}$. The previously published values for the activation energy of this reaction exhibit large variations; the one obtained in this work is in good agreement with the results of studies done in the same temperature range (Schuler et al., 1987; Suuberg et al., 1990). 


\section{Fate of the Fuel Nitrogen}

In this part, we intend to determine the whole parameters, which describes the fate of the fuel nitrogen during devolatilization on the one hand, and char oxidation on the other hand. The numerical model was used to determine these parameters by fitting experimental results.

Devolatilization. We have first determined the value of factor $\alpha$ from the quantification of nitrogen content in the coke and in the char obtained in the EFR under nitrogen atmosphere at $900^{\circ} \mathrm{C}$. The mass of fuel nitrogen in the char was found to be $80 \%$ of the nitrogen mass in the fuel, so the value of $\alpha$ is $\mathbf{0 . 2}$. For the determination of the factors $\eta_{V}, \beta_{V}, \gamma_{V}, \delta_{V}$, and $\varepsilon_{V}$, the devolatilization experiments described before were used, this time focusing on $\mathrm{N}$-containing species. The determination cannot be direct because a large number of combinations of these parameters enables a fit to the experimental results with the model. Nevertheless, it was possible to determine a range, for each parameter, that gives model-predicted concentrations of $\mathrm{N}$ species within the experimental error zone for each of the $\mathrm{N}$ species. In the case of $\mathrm{HCN}$, we have defined a zone of $\pm 10 \mathrm{ppmv}$ around the recorded value. Because of the uncertainty of measurements, we consider that nitrogen species whose measured concentrations are less than several ppmv (e.g., $\mathrm{NO}, \mathrm{N}_{2} \mathrm{O}$, and $\mathrm{NH}_{3}$ ) are in the range $0-10 \mathrm{ppmv}$. The possible range for the three parameters $\eta_{V}, \beta_{V}$, and $\delta_{V}$ which respect this assumption are given in Table 2. The value of $\gamma_{V}$ is then adjusted to respect the nitrogen balance. The range of values for these factors is rather narrow, which enables us to estimate them with a small uncertainty. We will retain the mean value for each of these factors; these values are also reported in Table 2. As expected, the amount of $\mathrm{NO}$ and $\mathrm{N}_{2} \mathrm{O}$ released during devolatilization is low. It can also be seen that the $\mathrm{HCN} / \mathrm{NH}_{3}$ ratio is very high. Substantial amounts of ammonia have been measured during devolatilization of

Table 2. Fuel nitrogen distribution in volatile matter (in mole fractions)

\begin{tabular}{lccccr}
\hline N species & $\mathrm{NO}$ & $\mathrm{N}_{2} \mathrm{O}$ & $\mathrm{N}_{2}$ & $\mathrm{HCN}$ & $\mathrm{NH}_{3}$ \\
\hline Parameter & $\eta_{V}$ & $\beta_{V}$ & $\gamma_{V}$ & $\delta_{V}$ & $\varepsilon_{V}$ \\
Range & $0-0.043$ & $0-0.061$ & $0.69-0.86$ & $0.14-0.20$ & $0-0.02$ \\
Chosen value & 0.02 & 0.03 & 0.77 & 0.17 & 0.01 \\
\hline
\end{tabular}


coals in this temperature range ( $\mathrm{Li}$ et al., 1996); the low value obtained here can be related to the high aromaticity of the char. Chars from high-rank coals have been reported to lead to high amounts of HCN (Glarborg et al., 2003; Solomon et al., 1982). The high heating rate used in our experimental setup also leads to an increase of the $\mathrm{HCN} / \mathrm{NH}_{3}$ ratio (Bassilakis et al., 1993; Solomon et al., 1982). These distribution factors for petcoke nitrogen in different nitrogen species in volatile matters for petcokes are therefore quite different from the ones observed for coals.

In Figure 5 we illustrate the results found with the model, using the factors in Table 2 and the experimental results. The computed concentrations of $\mathrm{NO}, \mathrm{N}_{2} \mathrm{O}$, and $\mathrm{NH}_{3}$ are in the measured range from 0 to $10 \mathrm{ppmv}$. After $1 \mathrm{~s}$, there is good agreement between the experiments and the model-predicted molar fraction of HCN. However, we can see in Figure 5 that, for short times, HCN concentrations and numerical simulations are not in accordance: we postulate that this gap is due to a temperature disturbance of the reacting zone by the water-cooled sampling probe. Another possibility is the possible presence of $\mathrm{HNCO}$ in volatile matters which could lead to a delayed formation of $\mathrm{HCN}$

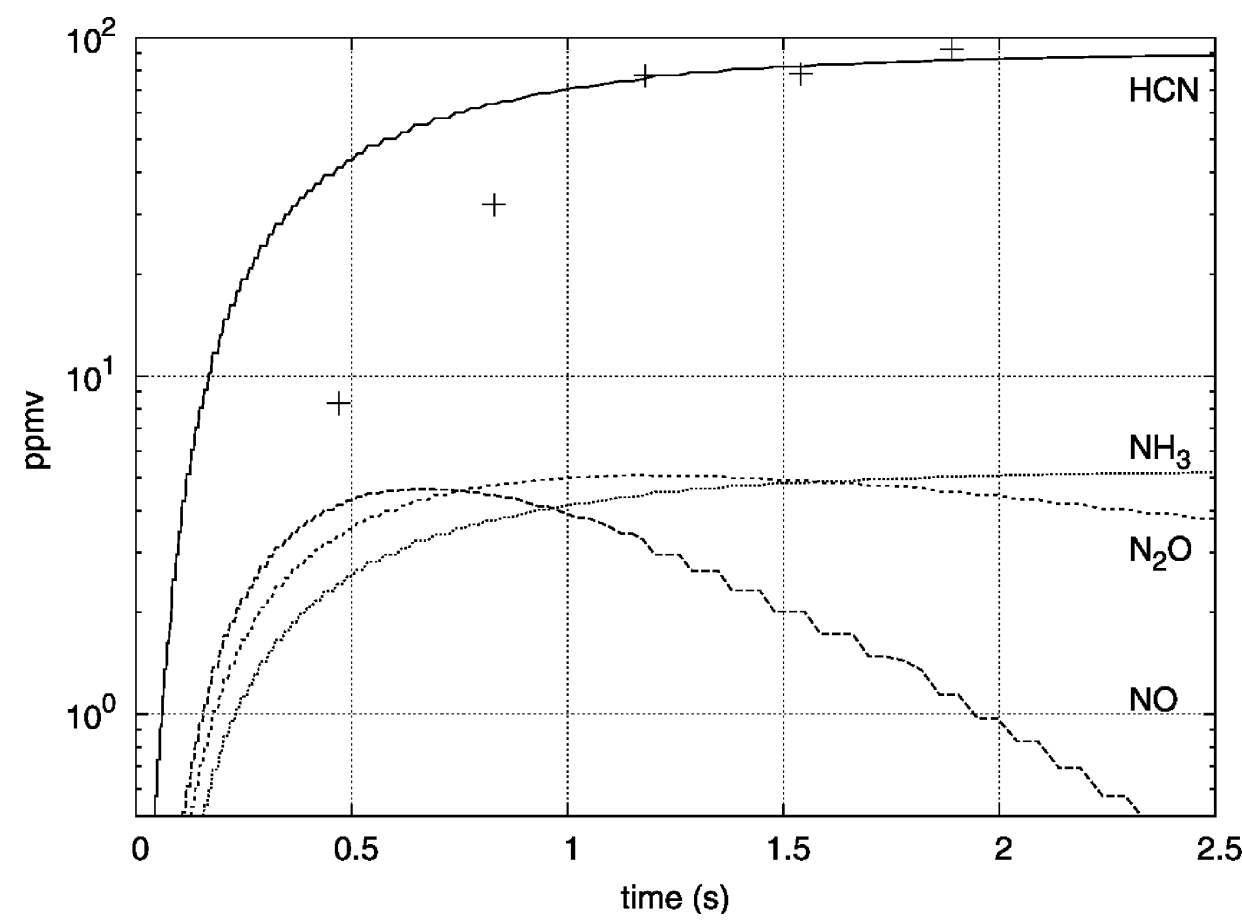

$\mathrm{HCN}+$

Figure 5. Molar fractions of $\mathrm{N}$ species in the EFR during devolatilization experiment (lines, model; symbols, experiments); $\mathrm{NO}, \mathrm{N}_{2} \mathrm{O}$, and $\mathrm{NH}_{3}$ were measured in concentrations below 1 ppmv. 
(Nelson et al., 1996). Nevertheless, because we are using a relatively high excess air configuration with a good mixing of gas and particles, there are no fuel-rich zones in which this chemical process could be expected.

Char Oxidation. We will now determine the nitrogen distribution factors during char oxidation (i.e., $\eta_{\mathrm{C}}, \beta_{\mathrm{C}}, \gamma_{\mathrm{C}}, \delta_{\mathrm{C}}$, and $\varepsilon_{\mathrm{C}}$ ). This was achieved by fitting the experimental results for the petcoke combustion in air inside the EFR with numerical simulations. Experiments were not carried out with a char but with the petcoke. From the previous sections,

- the parameters related to devolatilization have been obtained from pyrolysis experiments,

- the kinetics of heterogeneous reduction of NO on carbon was taken from a previous study, and

- the gas-phase chemistry is imposed by the kinetic mechanism.

Then, the only parameter that which controls the emission of NO during this set of experiments is the amount of each nitrogen-containing molecule formed in the primary heterogeneous combustion products.

NO is the only nitrogen species that was measured in quantities of more than several ppm. We have again defined an error zone of $\pm 25 \mathrm{ppmv}$ around the value of NO. Again we consider that nitrogen species whose measured concentrations were less than several ppm (e.g., $\mathrm{HCN}, \mathrm{N}_{2} \mathrm{O}$, and $\mathrm{NH}_{3}$ ) are in the zone $0-10 \mathrm{ppmv}$. The ranges for the obtained parameter values are given in Table 3 .

The uncertainty of these values are higher than in the case of devolatilization. The explanation of this observation is that the yield of oxidation of fixed nitrogen to NO is nearly independent of the nitrogen-containing molecule for the large amount of excess air used here (Glarborg et al., 2003). Then the nature of the primary molecule which results from fuel oxidation cannot been obtained from NO

Table 3. Fuel nitrogen distribution during char oxidation (in mole fractions)

\begin{tabular}{lcccrr}
\hline N species & $\mathrm{NO}$ & $\mathrm{N}_{2} \mathrm{O}$ & $\mathrm{N}_{2}$ & $\mathrm{HCN}$ & $\mathrm{NH}_{3}$ \\
\hline Parameter & $\eta_{C}$ & $\beta_{C}$ & $\gamma_{C}$ & $\delta_{C}$ & $\varepsilon_{C}$ \\
Range & $0.25-0.46$ & $0-0.15$ & $0-0.37$ & $0-0.54$ & $0-0.45$ \\
Chosen value & 0.35 & 0.15 & 0.10 & 0.20 & 0.20 \\
\hline
\end{tabular}


measurements. We can see in Figure 6 that there is a peak of $\mathrm{HCN}$ and $\mathrm{N}_{2} \mathrm{O}$ in the combustion zone; the concentrations of these two molecules fall down to zero after $1 \mathrm{~s}$. This concentration profile is different from the ones observed for coal combustion in a fluidized bed, in which $\mathrm{N}_{2} \mathrm{O}$ is the result of a secondary homogeneous formation from HCN (Miettinen et al., 1995). This behavior can be explained by the high temperature that is observed in this section of the reactor (higher than $1000^{\circ} \mathrm{C}$ ); as a consequence, the evolution of nitrous oxide is the result of the competition between its thermal decomposition and its formation from $\mathrm{HCN}$. The presence of this peak of $\mathrm{N}_{2} \mathrm{O}$ could be related to the direct heterogeneous formation from fuel-bound nitrogen (Molina et al., 2000).

The percentage of char $\mathrm{N}$ that is directly released as NO during the oxidation of the char is estimated in the range 25 to $46 \%$, which is a significant quantity. From these results, the quantity of char $\mathrm{N}$ released as $\mathrm{N}_{2} \mathrm{O}$ cannot exceed $15 \%$. The model also predicts that important quantities of char $\mathrm{N}$ can be released as $\mathrm{HCN}$ and $\mathrm{NH}_{3}$. The formation of HCN during the oxidation of char nitrogen has already been observed (Ashman et al., 1998; Jones et al., 1995; Winter et al., 1996). These two species are rapidly converted into NO by gas-phase reactions; this is the explanation for the very low concentrations present in the flow. Up to $54 \%$ of the char $\mathrm{N}$ might be released as $\mathrm{N}_{2}$, but, as is the case for $\mathrm{HCN}, \mathrm{NH}_{3}$, and $\mathrm{N}_{2} \mathrm{O}$, these results cannot establish which one of these species is actually released. $\mathrm{N}_{2}$ may not be the main nitrogen species formed during char oxidation.
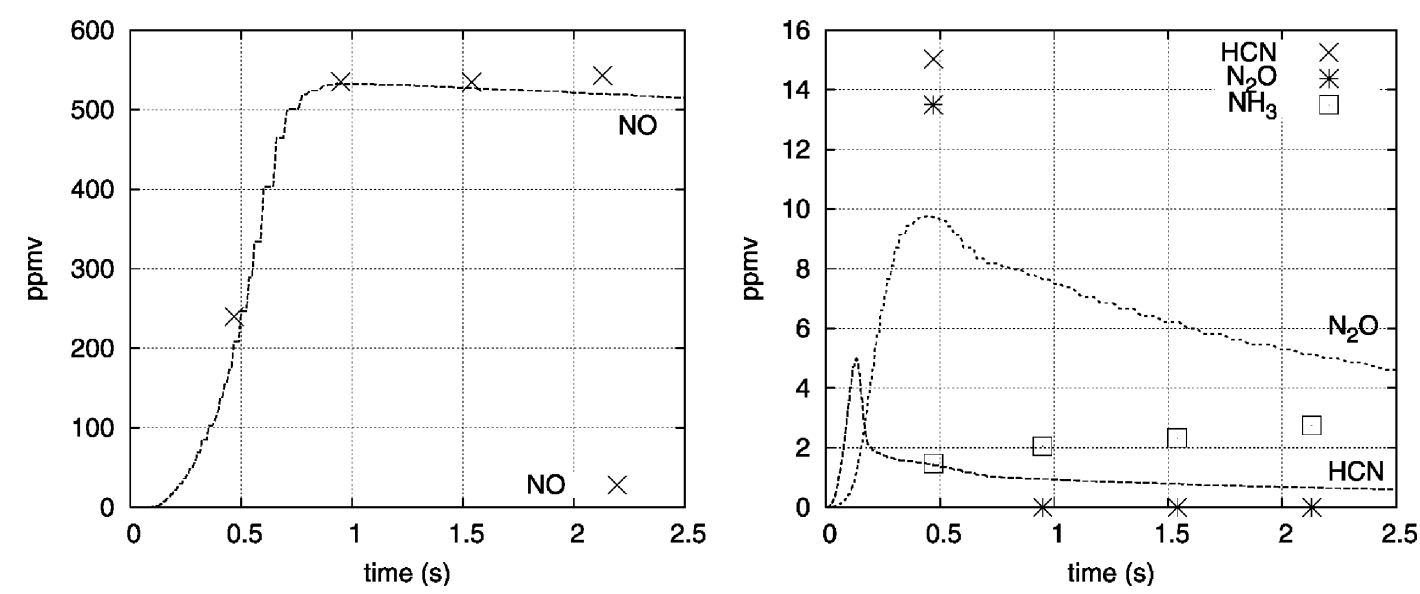

Figure 6. Molar fractions of $\mathrm{N}$ species in the EFR during combustion experiment (lines, model; symbols, experiments). The computed concentration of $\mathrm{NH}_{3}$ was below $0.1 \mathrm{ppmv}$. 
These original results for petcokes complement those found during the devolatilization study. Despite the high uncertainty of the values, we will retain a mean value for each factor, which we give in Table 3. In Figure 6 we illustrate the results found with our method during char oxidation. Curves are the results of numerical simulations including the factors previously defined in Table 3.

The simulated concentration profile of nitrogen monoxide is in good agreement with the experimental concentrations, but there are significant differences between measured and computed Concentrations of $\mathrm{HCN}, \mathrm{NH}_{3}$, and $\mathrm{N}_{2} \mathrm{O}$. These differences are difficult to analyze because the concentrations are two orders of magnitude lower than that of NO. This is mainly the consequence of the excess air used in our experiments and of the good mixing between gas and particles, which lead to a fast oxidation of the nitrogen-containing species.

The whole fuel nitrogen distribution model for petcoke can finally be described by Figure 7 .

\section{ANALYSIS OF THE MAIN MECHANISMS INVOLVED IN NO FORMATION AND DESTRUCTION}

In this section, the model, now completed, is used as a tool to analyze the mechanisms involved during the combustion of the petcoke and the formation of $\mathrm{NO}$ and to compare their contributions.

The temperature of the particles and that of the gas phase are determined by the major reactions (i.e., devolatilization, carbon residue oxidation, and volatile matters oxidation). NO formation and destruction reactions are minor reactions and take place at temperatures set by the principal reactions. In the next paragraphs, we first analyze the progress of the principal reactions, called combustion progress. Then the mechanisms involved in NO formation and destruction will be examined.

\section{Combustion Progress}

Temperature Evolution. The temperature profile along the EFR during the combustion of petroleum coke shown in Figure 2 is characterized by a rise until around $0.7 \mathrm{~s}$; particle and gases reach $1060^{\circ} \mathrm{C}$. This is where devolatilization takes place, as confirmed by the coke mass 


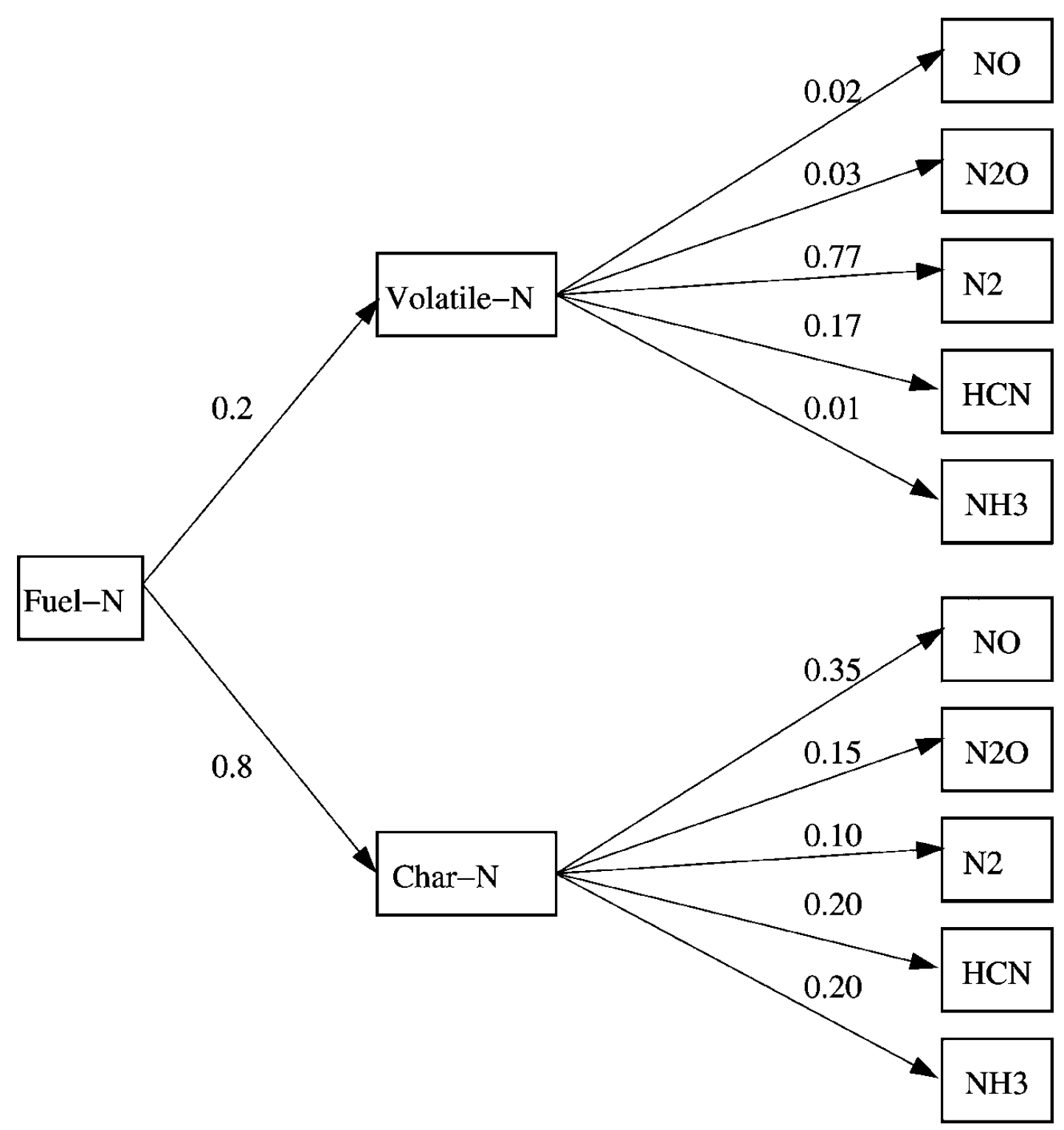

Figure 7. Fuel nitrogen distribution model for petcoke (in mole fractions).

evolution in Figure 8. Volatile matter oxidation generates a flame, resulting in a high-temperature zone.

Once devolatilization is finished, oxidation of the carbon residue occurs. The kinetics of this reaction is slow: during this period, the temperature of the particles and of the gaseous environment decreases progressively to reach the reactor's wall temperature.

Particle Mass Evolution. The thermochemical model indicates mass progress of each of the particle constituents during combustion time: coke and carbon residue (char). They are plotted in Figure 8, 


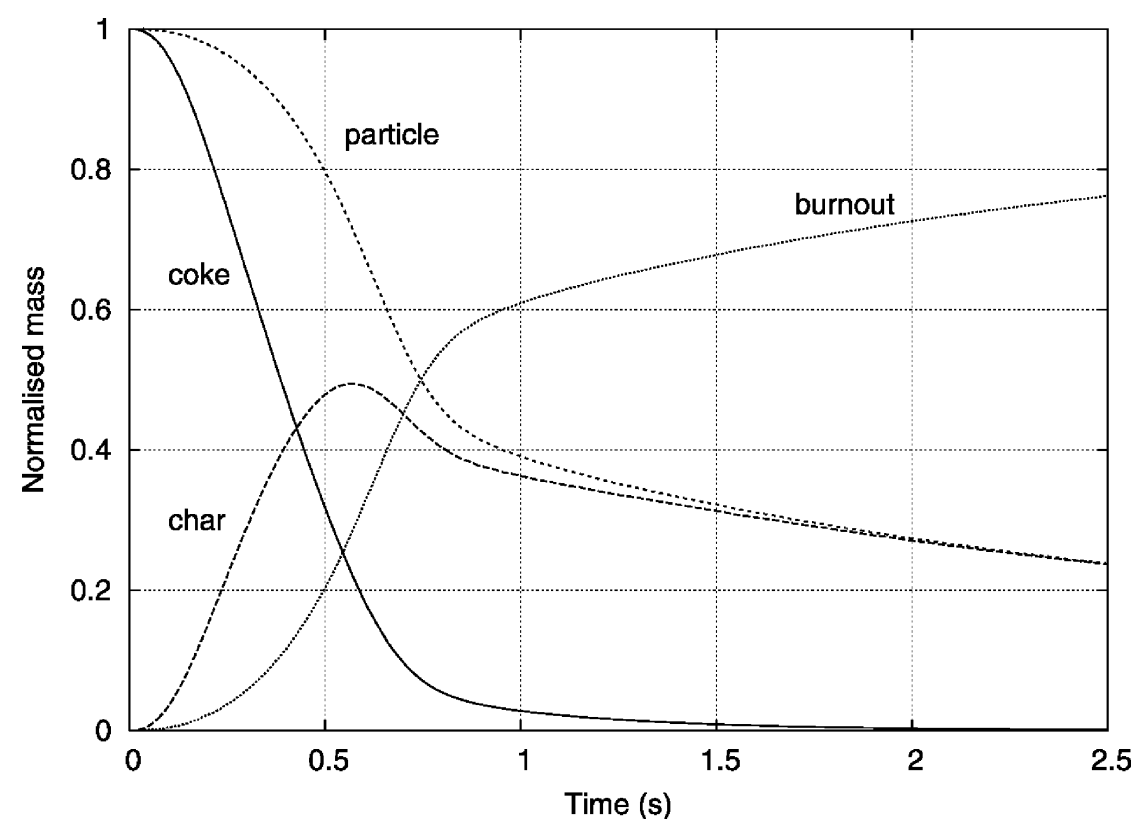

Figure 8. Model results for the normalized mass progress for coke, char, and particle (ash free), and for the overall burnout progress.

together with the total particle mass (without ash); the burnout, is also plotted.

The coke mass progress is an indicator for the devolatilization duration: the mass decreases rapidly until $0.8 \mathrm{~s}$, then decreases slowly until around $2 \mathrm{~s}$. The char oxidation is slow, as indicated by the small slope of the char mass curve after $0.6 \mathrm{~s}$. At the end of $2.5 \mathrm{~s}$, the combustion burnout is around $77 \%$. To check this part of the model, it would be helpful to do char burnout measurements. This is difficult because the ash balance method cannot be used for this measurement (the ash content of the coke is $0.43 \%$ ).

\section{Analysis of the Chemistry of Nitrogen Species}

Using the model, we intend to identify, among all the chemical reactions involved in the combustion process, those that are mainly responsible for the formation or the reduction of NO present in the gaseous products. In this paragraph, we discuss the results established for three kinds of reactions:

- global NO production from the 266 reactions in the gas phase;

- heterogeneous NO yield from fuel nitrogen, during 
-the devolatilization and during the char oxidation and -the char oxidation and

- heterogeneous NO reduction by reaction on the carbon residue.

NO Production in the Gas Phase. We have plotted the time-cumulated NO quantities produced (Figure 9a) or destroyed (Figure $9 b$ ) during the combustion process by each of the gaseous reaction. For clarity, they were converted into molar fractions (ppmv) of the total gas flow. Only the reactions that produce or destroy more than $10 \mathrm{ppmv}$ of $\mathrm{NO}$ were represented: eight reactions have produced more than $10 \mathrm{ppmv}$ of NO, and six reactions have destroyed more than $10 \mathrm{ppmv}$ of $\mathrm{NO}$ at the end of $3 \mathrm{~s}$. In all cases, radicals like $\mathrm{O}, \mathrm{H}, \mathrm{OH}, \mathrm{HNO}, \mathrm{NCO}$, or $\mathrm{NNH}$ take part in reactions.

The progress of NO molar fraction produced or destroyed is rapid before $0.7 \mathrm{~s}$ and slow after this time. This residence time corresponds to the end of the devolatilization and of the combustion of volatile matter. Some reactions produce more than $10^{5} \mathrm{ppmv}$ of NO, whereas others destroy nearly equivalent quantities. This shows that the NO molar concentration present inside the reactor, about 530 ppm (see Figure 6 after a residence time of $2 \mathrm{~s}$ ), results from the balance between the simultaneous production and destruction of very large quantities of NO in the gas phase. This quasi equilibrium of $\mathrm{NO}$ and $\mathrm{NO}_{2}$ is a consequence of the high excess air used in our experiments. The process is enhanced by the presence of hydrocarbons from volatile matter, which leads to the formation of $\mathrm{HO}_{2}$ in this temperature range (Hori et al., 1998), and this radical promotes the oxidation of $\mathrm{NO}$ to nitrogen dioxide.

Apart from this equilibrium, we can see that the main NO formation pathway is the oxidation of the HNO radical. These reactions of HNO are important after the devolatilization; this phenomenon is related to the relatively high amount of ammonia produced during the heterogeneous combustion. The contribution of the oxidation of NCO is one order of magnitude lower and is present during the oxidation of volatile matter and during the heterogeneous combustion.

This reaction pathway study also confirms the fact that nitrous oxide is formed in the volatile matter combustion zone through the classical homogeneous mechanism (i.e., the oxidation of $\mathrm{HCN}$ and subsequent reaction of $\mathrm{NCO}$ with $\mathrm{NO}$ ). Nevertheless, the temperature in this part of the reactor is higher that $1000^{\circ} \mathrm{C}$, which allows the thermal decomposition of $\mathrm{N}_{2} \mathrm{O}$. 


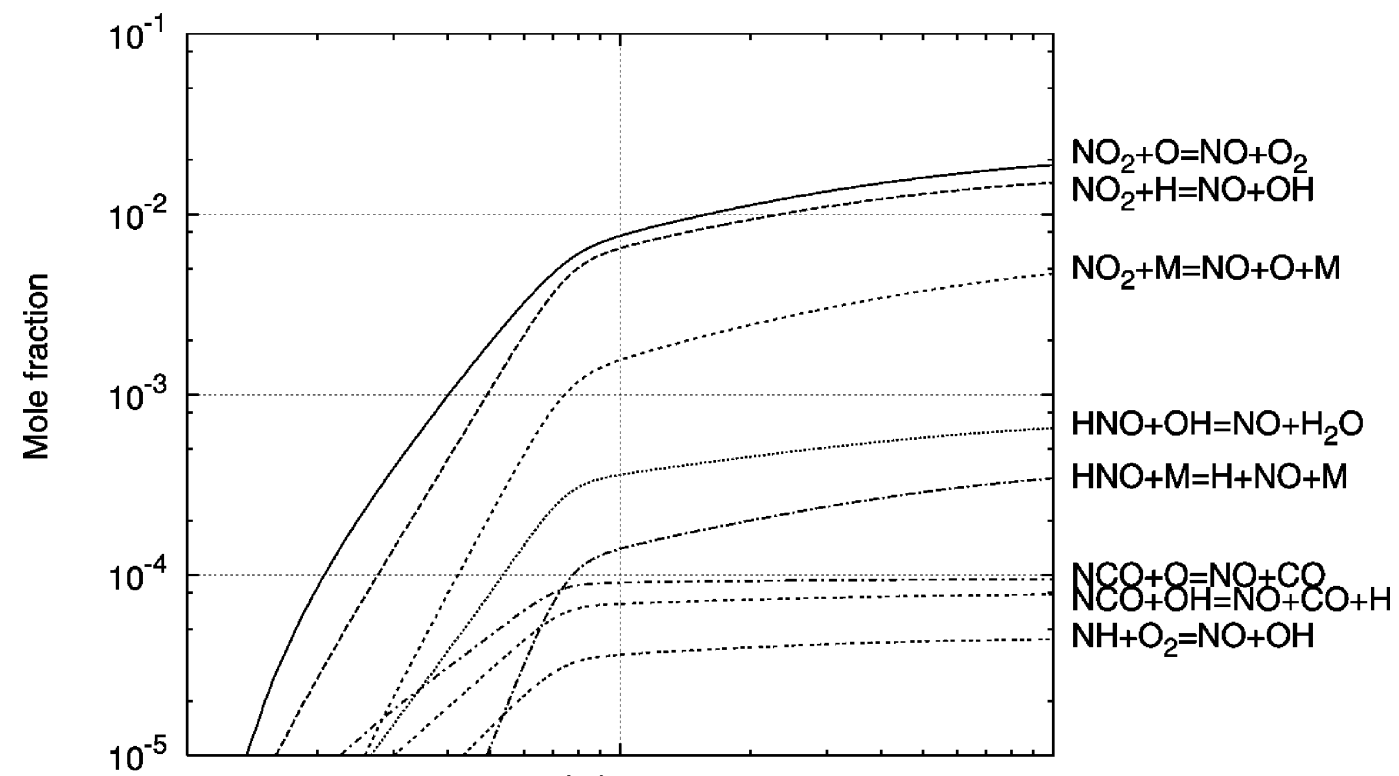

(a)

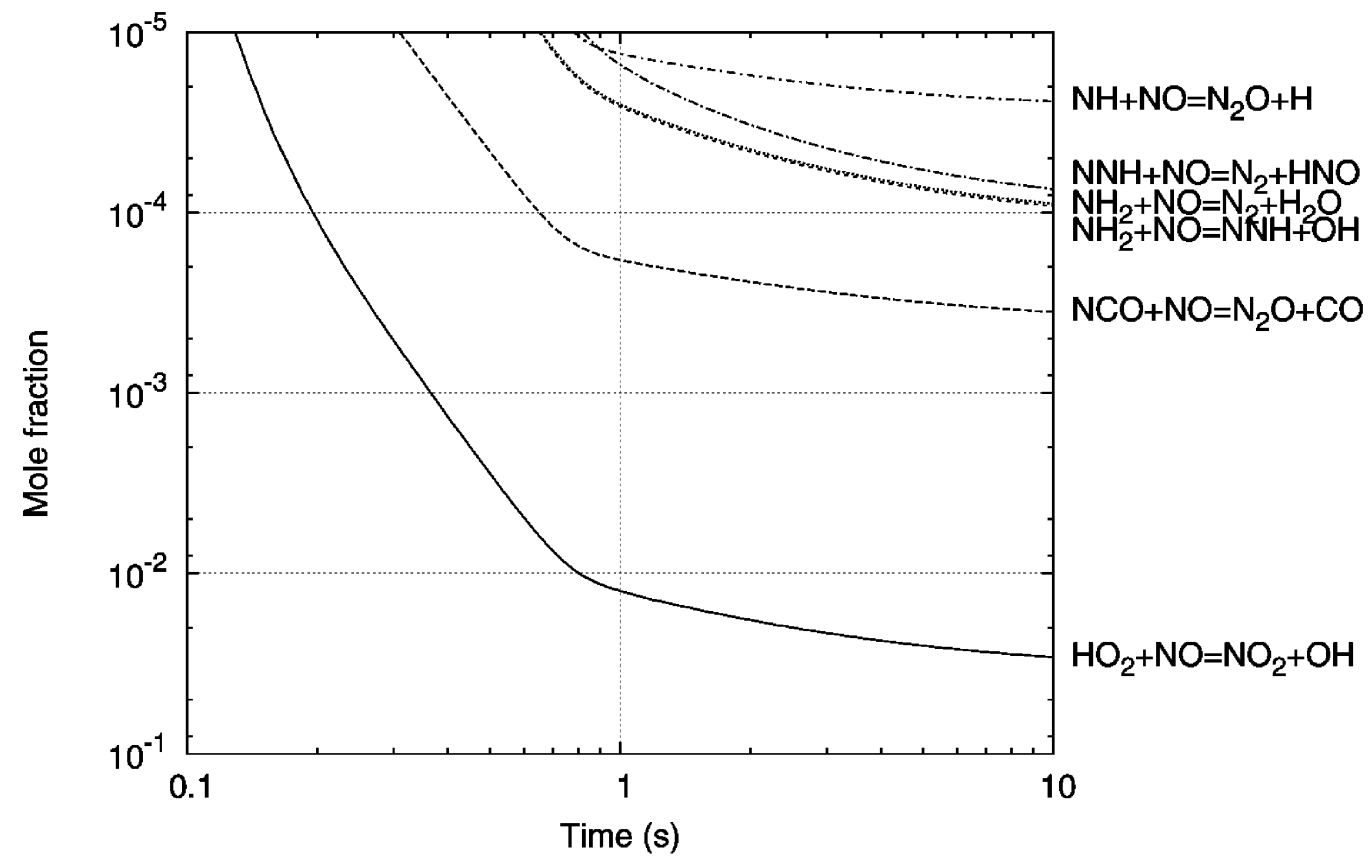

(b)

Figure 9. NO (a) produced and (b) destroyed for each gas-phase reaction of the detailed kinetic scheme.

NO Production and Reduction by Heterogeneous Reactions. In this part, we investigate the quantities of NO produced from fuel nitrogen and the quantities of NO destroyed on the carbon residue surface. We compare these quantities to those produced in the gas phase. Figure 10 shows 

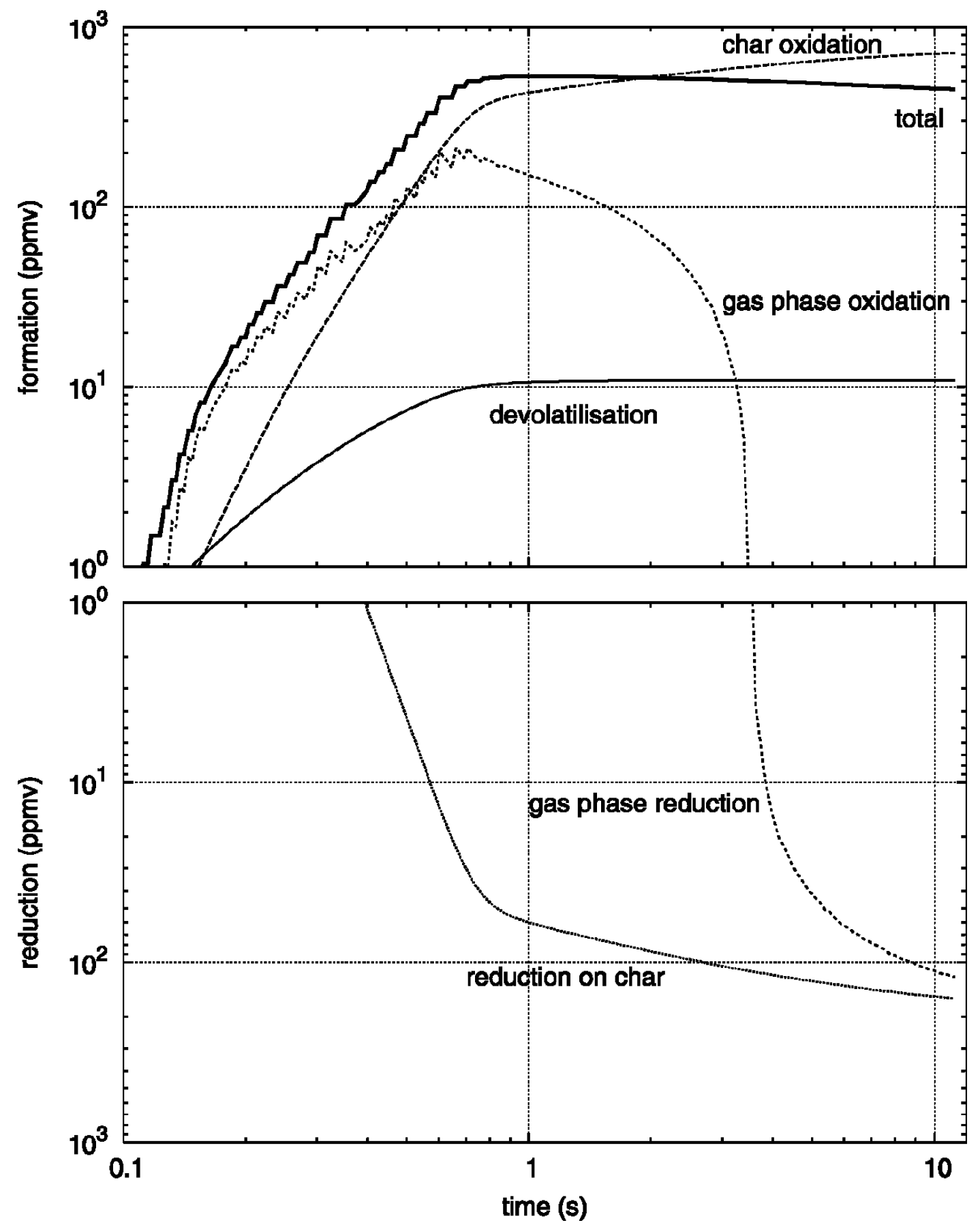

Figure 10. Reactions pathway.

- the molar fraction of NO resulting from fuel nitrogen release -during the devolatilisation, on the one hand, and -during the char oxidation, on the other hand;

- the molar fraction of NO globally formed by gas-phase reactions; 
- the molar fraction of NO destroyed by heterogeneous reaction with the carbon residue; and

- the molar fraction of NO in the gas phase, which results from the contributions of all the reactions that take place (total).

The result of all the reactions together is, as we can notice in Figure 10, that the cumulative quantity of NO present in the gas phase decreases.

The total NO concentration appears to increase until $0.7 \mathrm{~s}$, and then decreases slightly. Char oxidation is the main source of NO: it produces as much as $700 \mathrm{ppmv}$ of $\mathrm{NO}$ at the end of the reaction. We have thus previously noticed that NO was nondetectable during devolatilization experiments. The NO reduction on char reaction destroys important quantities of NO: more than $100 \mathrm{ppmv}$ is destroyed by this reaction after several seconds. The whole of the gas-phase reactions globally contributes to important NO production before $0.7 \mathrm{~s}$. After this, these reactions destroy important quantities of NO (more than $100 \mathrm{ppmv}$ ).

The final concentration of NO is $451 \mathrm{ppmv}$, this corresponds to a fuel-nitrogen conversion yield to NO of $18 \%$. This value is quite low compared to the ones observed for chars prepared from coals (De Soete, 1990; Johnsson, 1994). It has indeed been shown that the volatile nitrogen was a major source for NO formation. The low combustion rate of petcoke leads to a higher concentration of char in the reactor. This fact, together with the low concentration of gaseous hydrocarbons, enhances the importance of heterogeneous reduction.

We have simulated the combustion of a petroleum coke that did not contain fuel nitrogen, to quantify the cumulative quantities of thermal NO and prompt NO that are formed during the combustion. The temperature profile calculated by the model was not modified during the combustion of petcoke with or without nitrogen. This simulation shows that the NO produced is around $1 \mathrm{ppmv}$; thermal and prompt NO are formed in negligible quantities. Temperatures higher than $1800 \mathrm{~K}$ are required to observe the formation of significant amounts of nitrogen oxide through the thermal NO mechanism (Bowman, 1980; Hill and Smoot, 2000). Therefore, this result is not surprising because the temperature inside the reactor is always lower than $1350 \mathrm{~K}$.

The prompt NO mechanism is observed with fuel-rich conditions, and the main radical involved is $\mathrm{CH}_{\mathrm{x}}$, which can lead to cyanide species through reaction with molecular nitrogen (Fenimore, 1979; Hayhurst and Vince, 1980). The contribution of the prompt NO mechanism to the total NO 
formation is related to the low volatile matter content of the petcoke. Then the concentration of hydrocarbon radicals is too low and hydrocarbon radicals are not expected to be present in high concentration in the gas phase.

\section{CONCLUSIONS}

We have developed a thermochemical model which describes the combustion of a petcoke in EFR conditions, close to precalciner conditions. This model takes into account heat balance for particles and for the gas phase, and chemical species transfer between the particles and the gas phase. The gas-phase chemistry is treated using detailed chemistry with reversible reactions.

We have determined the kinetic parameters and the factors for fuelnitrogen distribution. This was achieved thanks to specific experiments for each reaction.

The numerical model, once completed with these parameters, first enabled analysis of the progress of the main reactions of combustion such as devolatilization, char oxydation, and volatile matter oxidation. The temperature increases until $1060^{\circ} \mathrm{C}$ in the flame zone, then decreases to the reactor walls temperature $\left(900^{\circ} \mathrm{C}\right)$. In the flame zone, devolatilization occurs and char oxidation begins.

The numerical model then enabled us to explain the presence of 530 ppmv of NO at the end of the combustion as the sum of the contributions of different mechanisms. In the gas phase, we showed that there is a balance between some reactions that produce and others that destroy very important quantities of NO. The global contribution of this to the total NO concentration is important in the flame zone and negligible at the end of the combustion. The quantities of thermal and prompt NO are low. The fuel nitrogen that is released during the devolatilization produces very low quantities of NO. Char oxidation is the main mechanism to produce NO from fuel nitrogen: $600 \mathrm{ppmv}$ have been formed by this reaction at the end of the combustion process.

\section{NOMENCLATURE}

$A_{\mathrm{dev}} \quad$ preexponential factor for devolatilization $\left(\mathrm{s}^{-1}\right)$

$A_{\mathrm{NO}, \mathrm{C}}$ preexponential factor for $\mathrm{NO}$ reduction on char $\left(\mathrm{mol} \cdot \mathrm{m}^{-2}\right.$. $\left.\mathrm{s}^{-1} \cdot \mathrm{atm}^{-1}\right)$

$A_{\mathrm{ox}, \mathrm{C}} \quad$ preexponential factor for char oxidation $\left(\mathrm{kg} \cdot \mathrm{m}^{-2} \cdot \mathrm{s}^{-1} \cdot \mathrm{atm}^{-1}\right)$ 
$D_{e} \quad$ effective diffusivity in the porous structure of the char $\left(\mathrm{m} \cdot \mathrm{s}^{-2}\right)$

$D_{\text {Fick }} \quad$ Fick diffusion coefficient $\left(\mathrm{m} \cdot \mathrm{s}^{-2}\right)$

$D_{\text {Knud }} \quad$ Knudsen diffusion coefficient $\left(\mathrm{m} \cdot \mathrm{s}^{-2}\right)$

$d_{\text {pore }} \quad$ mean pore diameter for the char particle $(\mathrm{m})$

$E_{a \mathrm{dev}} \quad$ activation energy for devolatilization $\left(\mathrm{kJ} \cdot \mathrm{mol}^{-1}\right)$

$E_{a \mathrm{NO}, \mathrm{C}}$ activation energy for $\mathrm{NO}$ reduction on $\operatorname{char}\left(\mathrm{kJ} \cdot \mathrm{mol}^{-1}\right)$

$E_{a \mathrm{ox}, \mathrm{C}}$ activation energy for char oxidation $\left(\mathrm{kJ} \cdot \mathrm{mol}^{-1}\right)$

$k_{\mathrm{dev}} \quad$ kinetic constant for devolatilization $\left(\mathrm{s}^{-1}\right)$

$k_{\mathrm{NO}, \mathrm{C}}$ kinetic constant for NO reduction on char $\left(\mathrm{mol} \cdot \mathrm{m}^{-2} \cdot \mathrm{s}^{-1} \cdot \mathrm{atm}^{-1}\right)$

$k_{\mathrm{ox}, \mathrm{C}} \quad$ kinetic constant for char oxidation $\left(\mathrm{kg} \cdot \mathrm{m}^{-2} \cdot \mathrm{s}^{-1} \cdot \mathrm{atm}^{-1}\right)$

$m_{\text {coke }} \quad$ mass of petroleum coke in the cell $(\mathrm{g})$

$m_{\mathrm{C}} \quad$ mass of carbon in the cell $(\mathrm{g})$

$M_{\mathrm{C}} \quad$ atomic mass of carbon $\left(\mathrm{g} \cdot \mathrm{mol}^{-1}\right)$

$M_{\mathrm{O}_{2}} \quad$ molecular weight of oxygen $\left(\mathrm{g} \cdot \mathrm{mol}^{-1}\right)$

$P_{\mathrm{NO}, s} \quad$ NO partial pressure at particle surface (atm)

$P_{\mathrm{O}_{2}, s} \quad$ oxygen partial pressure at particle surface (atm)

$R \quad$ gas law constant

$r_{\text {mas }} \quad$ mass $\mathrm{CO} / \mathrm{CO}_{2}$ ratio in char oxidation products

$S_{\mathrm{sp}} \quad$ specific surface area of the char $\left(\mathrm{m}^{2} \cdot \mathrm{g}^{-1}\right)$

$T_{p} \quad$ particle temperature $(\mathrm{K})$

$T_{\text {env }} \quad$ temperature of the gas phase (K)

$\alpha \quad$ fraction of coke nitrogen devolatilized

$\beta_{C}, \beta_{V}$ conversion of char nitrogen and primary volatile matter nitrogen to $\mathrm{N}_{2} \mathrm{O}$

$\gamma_{C}, \gamma_{V}$ conversion of char nitrogen and primary volatile matter nitrogen to $\mathrm{N}_{2}$

$\delta_{C}, \delta_{V}$ conversion of char nitrogen and primary volatile matter nitrogen to $\mathrm{HCN}$

$\varepsilon_{C}, \varepsilon_{V} \quad$ conversion of char nitrogen and primary volatile matter nitrogen to $\mathrm{NH}_{3}$

$\varepsilon_{p} \quad$ porosity of the particle

$\eta_{\mathrm{ox}} \quad$ efficiency factor for char oxidation

$\eta_{C}, \eta_{V} \quad$ conversion of char nitrogen and primary volatile matter nitrogen to NO

$\eta_{\mathrm{NO}} \quad$ efficiency factor for NO reduction on char

$\rho_{g} \quad$ gas density in the boundary layer of the particle $\left(\mathrm{g} \cdot \mathrm{m}^{-3}\right)$

$\tau_{p} \quad$ tortuosity of the porous structure

$\Phi \quad$ Thiele modulus 


\section{REFERENCES}

Aarna, I. and Suuberg, E.M. (1997) A review of the kinetics of the nitric oxidecarbon reaction. Fuel, 76, 475-491.

Adanez, J., de Diego, L.F., Gayan, P., Armesto, L., and Cabanillas, A. (1996) Modelling of sulfur retention in circulating fluidized bed combustors. Fuel, $75,262-270$.

Al-Haj-Ibrahim, H. and Morsi, B.I. (1992) Desulfurization of petroleum coke: A review. Ind. Eng. Chem. Res., 31, 1835-1840.

Amand, L.E., Leckner, B., and Andersson, S. (1991) Formation of $\mathrm{N}_{2} \mathrm{O}$ in circulating fluidized bed boilers. Energy Fuels, 5, 815-823.

Arthur, J.R. (1951) Reaction between carbon and oxygen. Trans. Farad. Soc., 47, 164-178.

Ashman, P.J., Haynes, B.S., Buckley, A.N., and Nelson, P.F. (1998). The Fate of Char Nitrogen in Low Temperature Oxidation, Proc. Combust. Instit., 27, 3069-3076.

Ashman, P.J., Haynes, B.S., Nicholls, P.M., and Nelson, P.F. (2000) Interaction of Gaseous NO with Char During the Low Temperature Oxidation of Coal Chars, Proc. Combust. Instit., 28, 2171-2180.

Bassilakis, R., Zhao, Y., Solomon, P.R., and Serio, M.A. (1993) Sulfur and nitrogen evolution in the argonne coals: Experiment and modeling. Energy Fuels, 710-720.

Baxter, L.L., Mitchell, R.E., Fletcher, T.H., and Hurt, R.H. (1996) Nitrogen release during coal combustion. Energy Fuels, 10, 188-196.

Bowman, C.T. (1980) Kinetics of pollutant formation and destruction in combustion. Prog. Energy Combust. Sci., 1, 33-45.

Commandré J.-M., Stanmore, B.R., and Salvador, S. (2002) The high temperature reaction of carbon with nitric oxide. Combust. Flame, 128, 211-216.

Dagaut, P. and Lecome, F. (2003) Experimental and kinetic modeling study of the reduction of NO by hydrocarbons and interactions with SO2 in a JSR at 1 atm. Fuel, 82, 1033-1040.

De. Soete, G.G. (1990) Heterogeneous $\mathrm{N}_{2} \mathrm{O}$ and NO Formation from Bound Nitrogen Atoms During Coal Combustion, Proc. Combust. Instit., 23, 1257-1264.

EPA (1994) Alternative Control Techniques Document-Nox Emissions from Cement Manufacturing. Tech. rept. EPA-453/R94-004.

Fenimore, C.P. (1979) Studies of Fuel-Nitrogen in Rich Flame Gases, Proc. Combust. Instit., 17, 661-669.

Förtsch, D., Kluger, F., Schnell, U., Spliethoff, H., and Hein, K.R.G. (1998) A Kinetic Model for the Prediction of NO Emissions from the Staged Combustion of Pulverized Coal, Proc. Combust. Instit., 27, 3037-3044. 
Fuertes, A.B. and Artos, V.(1992) Sulphur retention by ash during fluidized bed combustion of bituminous coals. Fuel, 71, 507-511.

Glarborg, P., Jensen, A.D., and Johnsson, J.E. (2003). Fuel nitrogen conversion in solid fuel fired sytems. Prog. Energy Combust. Sci., 29, 89-113.

Goel, S., Molina, A., and Sarofim, A.F. (2002) Factors influencing the time resolved evolution of $\mathrm{NO}, \mathrm{HCN}$, and $\mathrm{N}_{2} \mathrm{O}$ during char oxidation at fluidized bed conditions. Energy Fuels, 16, 823-830.

Guo, F. and Hecker, W. (1998) Kinetics of NO Reduction by Char: Effects of Coal Rank, Proc. Combust. Instit., 27, 3085-3091.

Hayhurst, A.N. and Vince, I.M. (1980) Nitric oxide formation from $\mathrm{N}_{2}$ in flames: The importance of "prompt" NO. Prog. Energy Combust. Sci., 6, 35-51.

Hill, S.C. and Smoot, L.D. (2000) Modeling of nitrogen oxides formation and destruction in combustion systems. Prog. Energy Combust. Sci., 26, 417-458.

Hori, M., Matsunaga, N., Marinov, N., Pitz, W., and Westbrook, C. (1998) An Experimental an Kinetic Calculation of the Promotion Effect of Hydrocarbons on the NO-NO ${ }_{2}$ Conversion in Flow Reactor, Proc. Combust. Instit., 27, 389-396.

Iliuta, I., Dam-Johansen, K., and Jensen, L.S. (2002a) Mathematical modeling of an in-line low-Nox calciners. Chem. Eng. Sci., 57, 805-820.

Iliuta, I., Dam-Hohansen, K., Jensen, A., and Jensen, L.S. (2002b) Modeling of inline low-NOx calciners-A parametric study. Chem. Eng. Sci., 57, 789-803.

Illan-Gomez, M.J., Linares-Solano, A., Salinas-Martinez de Lecea, C., and Calo, J.M. (1993) NO reduction by activated carbons. 1. The role of carbon porosity and surface area. Energy Fuels, 7, 146-154.

Illan-Gomez, M.J., Linares-Solano, A Radovic, L.R., and Salinas-Martinez de Lecea, C. (1995) NO reduction by activated carbons. 2. Catalytic effect of potassium. Energy Fuels, 9, 97-103.

Johansen, V., Egelov, A.H., and Eirikson, A. (1986) Emissions of Nox and $\mathrm{SO}_{2}$ form cement clinker burning installations. Zement. Kalk. Gips., 39(10), $558-559$.

Johnsson, J.E. (1994). Formation and reduction of nitrogen oxides in fluidized bed combustion. Fuel, 73, 1398-1415.

Jones, J.M., Harding, A.W., Brown, S.D., and Thomas, K.M. (1995). Detection of reactive intermediate nitrogen and sulfur species in the combustion of carbons that are models for coal chars. Carbon, 33, 833.

Kee, R.J., Rupley, M., and Miller, J.A. (1990) CHEMKIN II: A FORTRAN Chemical Kinetics Package for the Analysis of the Gas-Phase Chemical Kinetics. Sandia National Laboratories report SAND89-8009.

Kobayashi, H., Howard, J.B., and Sarofim, A.F. (1976) Coal Devolatilization at High Temperatures, Proc. Combust. Instit., 16, 411-425.

Kramlich, J.C. and Linak, W.P. (1994) Nitrous oxide behavior in the atomosphere, and in combustion and industrial systems. Prog. Energy Comb Sci., 20, 149-202. 
Laurendeau, N.M. (1978) Heterogeneous kinetics of coal char gasification and combustion. Prog. Energy Combust. Sci., 4, 221-270.

Ledesma, E.B., Li, C.-Z., Nelson, P.F., and Mackie, J.C. (1998) Release of HCN, $\mathrm{NH} 3$, and HNCO from the thermal gas-phase cracking of coal pyrolysis tars. Energy Fuels, 12, 536-541.

Li, C.-Z., Nelson, P.F., Ledesma, E.B., and Mackie, J.C. (1996) An Experimental Study of the Release of Nitrogen from Coals Pyrolyzed in Fluidized-Bed Reactors, Proc. Combust. Instit., 26, 3205-3211.

Miettinen, H., Paulsson, M., and Strömberg, D. (1995) Laboratory study of $\mathrm{N}_{2} \mathrm{O}$ formation from burning char particles. Energy Fuels, 9, 10-19.

Miller, J.A., and Bowman, C.T. (1989) Mechanism and modeling of nitrogen chemistry in combustion. Prog. Energy Combust. Sci., 15, 287-338.

Molina, A., Eddings, E.G., Pershing, D.W., and Sarofim, A.F. (2000) Char nitrogen conversion: Implication to emissions from coal-fired utility boilers. Prog. Energy Combust. Sci., 26, 507-531.

Nelson, P.F., Li, C.-Z., and Ledesma, E. (1996) Formation of HNCO from the rapid pyrolysis of coals. Energy Fuels, 10, 264-265.

Nicholls, P.M. and Nelson, P.F. (2000) Detection of HNCO during the lowtemperature combustion of coal chars. Energy Fuels, 14, 943-944.

Radhakrishnan, K. and Hindmarsh, A.C. (1993) Description and Use of LSODE, the Livermore Solver for Ordinary Differential Equations. LLNL report UCRL-ID-113855.

Salvador, S., Commandre, J.M., and Stanmore, B. (2002) Reaction rate for the oxidation of higly sulphurised petroleum cokes: The influence of thermogravimetric conditions and some coke properties. Fuel, 82, 715-720.

Salvador, S., Commandre, J.-M., Stanmore, B.R., and Gadiou, R. (2004). The catalytic effect of vanadium on the reactivity of petroleum cokes with NO. Energy Fuels, 18, 296-301.

Schuler, J., Baumann, H., and Klein, J. (1987) Kinetics of NO Reduction by Coal char. 7th International Conference on Coal Science, 26-30 October, Elsevier, Amsterdam, pp. 857-860.

Sheng, C., Xu, M., Zhang, J., and Xu, Y. (2000) Comparison of sulphur retention by coal ash in different types of combustors. Fuel Proc. Technol., 64, 1-11.

Smith, I.W. (1978) The intrinsic reactivity of carbons to oxygen. Fuel, 57, 409-414.

Solomon, P.R., Hamblen, D.G., Carangelo, R.M., and Krause, J.L. (1982) Coal Thermal Decomposition in an Entrained Flow Reactor, Experiments and Theory, Proc. Combust. Instit., 19, 1139-1149.

Song, Y.H., Beer, J.M., and Sarofim, A.F. (1977) Fate of fuel nitrogen during pyrolysis and oxidation. In 2nd Symposium on Stationary Source Combustion, New Orleans, LA, vol. 4. EPA report EPA-60017-77-073. 
Suuberg, E.M., Teng, H., and Calo, J.M. (1990) Studies on the Kinetics and Mechanism of the Reaction of NO with Carbon, Proc. Combust. Instit., 23, 1199-1205.

Thiele, E.W, (1939) Relation between catalytic activity and size of particle. Ind. Eng. Chem., 31, 916-920.

Uzun, D. and Ozdogan, S. (1998) Correlations for the sulfur contents of Turkish coals exposed to ashing and devotilisation conditions at $750^{\circ} \mathrm{C}$ and $950^{\circ} \mathrm{C}$. Fuel, 77, 1599-1604.

Van De Steene, L., Salvador, S., and Charnay, G. (2000) Controling powdered fuel combustion at low temperature in a new entrained flow reactor. Combust. Sci. Technol., 159, 255-279.

Wendt, J.O.L., Wootan, E.C., and Corley, T.L. (1983) Postflame behavior of nitrogenous species in the presence of fuel sulfur. I : Rich, moist, $\mathrm{CO} / \mathrm{Ar} / \mathrm{O}_{2}$ flames. Combust. Flame, 49, 261-274.

Wheeler, A. (1951) Reaction rates and selectivity in catalyst pores. Adv. Catal., 3, 249-327.

Winter, F., Wartha, C., Löffler, G., and Hofbauer, H. (1996) The NO and $\mathrm{N}_{2} \mathrm{O}$ formation mechanism during devolatilization and char combustion under fluidized beds conditions. Proc. Combust. Instit., 26, 3325.

Zhang, H. and Fletcher, T.H. (2001) Nitrogen transformations during secondary tar pyrolysis. Energy Fuels, 15, 1512-1522. 